\title{
Soil Chemical Fertility Change Over 4 Decades In The Morvan Mountains And Influence of Tree Species (Burgundy, France)
}

Clesse Margaux ( $\nabla$ margaux.clesse@inrae.fr)

INRAE, BEF, F-54000 Nancy, France https://orcid.org/0000-0002-5302-3076

Legout Arnaud

INRAE, BEF, F-54000 Nancy, France

Ranger Jacques

INRAE, BEF, F-54000 Nancy, France

Zeller Bernd

INRAE, BEF, F-54000 Nancy, France

Van Der Heijden Gregory

INRAE, BEF, F-54000 Nancy, France

\section{Research Article}

Keywords: Nutrient pools, Tree species, Acidification, Podzolization, Recovery, Ecosystem services

Posted Date: November 12th, 2021

DOI: https://doi.org/10.21203/rs.3.rs-1047258/v1

License: (c) (1) This work is licensed under a Creative Commons Attribution 4.0 International License. Read Full License 


\section{Abstract}

Background: Intensive silvicultural practices and the planting of monospecific forests of coniferous, more productive compared to hardwoods, may threaten over the mid to long-term the sustainability of soil chemical fertility of forest ecosystems and is a major concern for forest managers and policy.

Methods: We investigated the tree species effect (Quercus sessiliflora Smith, Fagus sy/vatica L., Picea abies Karst., Pseudotsuga menziesii Mirb. Franco., Abies nordmanniana Spach. and Pinus nigra Arn. ssp laricio Poiret var corsicana) on the change over time of soil chemical properties and nutrient pool sizes in the mineral and organic layers of the soil during the 45 years after the plantation of the Breuil-Chenue common garden experiment (Burgundy, France). The organic and mineral soil layers down to $70 \mathrm{~cm}$ depth were sampled in the different monospecific plots in 1974, 2001 and 2019.

Results: The $\mathrm{Ca}$ and $\mathrm{Mg}$ exchangeable pools and soil pH increased over the entire soil profile in most stands. However, the decrease of $\mathrm{pH}$ and the increase of exchange acidity in the topsoil layers under conifers and the overall decrease of exchangeable $\mathrm{K}$ pools in most stands highlighted that soil acidification is still on-going at this site but the intensity of this process depends on the tree species. Indeed, three groups of species could be distinguished: i) Nordmann fir / Norway spruce where acidolysis and chelation occurred, resulting in the most pronounced $\mathrm{pH}$ decrease in the topsoil, ii) Douglas fir / Laricio pine where acidification caused by elevated nitrification rates is probably currently compensated by larger weathering and/or atmospheric depositions fluxes, iii) and oak / beech where soil acidification was less intense. Counterintuitively, soil acidification at this site resulted in an increase in soil CEC which limited the loss of nutrient cations. This change in soil CEC was most likely explained by the precipitation/dissolution dynamics of aluminium (Al) (hydr)oxides in the interfoliar space of phyllosilicates and/or the increase in soil carbon (C) content in the topsoil layers.

Conclusion: Tree species greatly and fairly rapidly ( $<45$ years) influence the soil chemical fertility and the pedogenetic processes which in turn may impact forest ecosystem functions and services.

\section{Background}

In Europe and in North America, forest land cover reached its minimum around the beginning of the 18th century due to the overexploitation of forest resources (Kaplan et al., 2009). Forest land cover has since then greatly increased helped by the afforestation policies and the use of new energy sources during the second half of the 20th century (Puech, 2009). Vast areas were planted with productive coniferous tree species that were translocated within Europe (e.g. Norway spruce, Picea abies Karst. and Scots Pine, Pinus sy/vestris L.) or imported from North America (e.g. Sitka spruce, Picea sitchensis Bong. and Douglas fir, Pseudostuga menziesii Mirb.). In many cases, native deciduous forest stands such as beech and oak were converted to coniferous plantations to increase forest productivity (Bouvet et al., 2019). Forest plantation still remains a common silvicultural practice. 
Tree species impact many different processes and fluxes at different ecosystem levels as reported by the numerous reviews and studies (Augusto et al., 2015, 2002; De Schrijver et al., 2007). Tree species may influence (i) the geochemical cycling (atmospheric deposition, mineral weathering, leaching) and (ii) the biological cycling (uptake, immobilization in biomass, litterfall, mineralization) as defined by Legout et al., (2020):

(i) Tree species have different capacities to scavenge atmospheric dry and occult deposition, depending on their canopy architecture, height, foliage type and stand Atmospheric deposition and concentrations of nitrogen and sulfur in throughfall are generally higher under coniferous stands compared to hardwood stands (Augusto et al., 2002; De Schrijver et al., 2007). According to Augusto et al., (2002), Norway spruce stands collect more atmospheric depositions than beech or oak (respectively $+187 \%,+59 \%$ et $+99 \%$ deposition under canopy compared to bulk deposition) and nitrogen and sulfur deposits are higher under conifers than deciduous trees (Rothe et al., 2002; Verstraeten et al., 2012). Augusto et al., (2002) also showed that mineral weathering was enhanced under Norway spruce stands ( 2 to 3 times higher) compared to hardwood stands. Lastly, tree species may also influence nutrient leaching (Augusto et al., 2002; Legout et al., 2016). Tree species exert a control over $\mathrm{N}$ mineralization and nitrification processes (Andrianarisoa et al., 2010; Zeller et al., 2019) and soil acidity may increase when nitrate production exceeds nitrate consumption (Legout et al., 2016).

(ii) Per unit of biomass produced, uptake and immobilization of nutrients in aerial biomass is usually higher in hardwood species than for coniferous species (Augusto et al., 2002). However, even if nutrient contents in aerial biomass are usually higher for hardwood species than for coniferous species, the coniferous species produce more biomass and their rotation lengths are shorter than hardwood species (Augusto et al., 2002; Binkley, 1995). Depending on litterfall mass and chemical composition, tree species may also influence the pools of carbon and nutrients in the organic layer (Carnol and Bazgir, 2013; Moukoumi et al., 2006; Vesterdal et al., 2008). Slower organic matter decomposition rates in coniferous stands have been reported (Binkley, 1995; Rovira and Vallejo, 2002) which may also contribute to increase soil acidity. Gruba and Mulder (2015) showed that tree species influence the cationic exchange capacity in the soil, with an organic cationic exchange capacity per mass of carbon greater for hardwood species compared to coniferous species.

As a result of these different processes, tree species influence soil acidification and chemical fertility over the long-term. Soil acidification processes have been shown to be enhanced under Norway spruce stands compared to other species (oak., beech, birch, Douglas fir, pine,) (Augusto et al., 2002, 2000, 1998; Bergkvist and Folkenson, 1995). Several studies demonstrated that exchangeable pools of $\mathrm{Ca}, \mathrm{Mg}$ and $\mathrm{K}$ are generally lower (Cremer and Prietzel, 2017; Ranger, 1995) and solution concentrations in $\mathrm{Al}$ and $\mathrm{H}^{+}$are generally higher (Brown and lles, 1991; Legout et al., 2016) under coniferous stands compared to broadleaved stands. Despite numerous studies, our understanding of the impact of different tree species on soil chemical fertility is yet incomplete because very few studies have been able to report the long term effects of different tree species on the soil chemical fertility. Over short time periods (year to decade), the 
entire extent of tree species effects may not be resolvable because changes in soil fertility may be small due to slow soil processes.

Yet, understanding the effects of tree species on the long-term fertility of forest soils is of utmost importance to ensure its sustainability because (i) forests generally grow on acidic and nutrient poor soils, (ii) which in many cases have been severely impacted by the elevated acidic atmospheric inputs during the 20th century, (iii) although atmospheric deposition of sulphur has decreased since the 1980s (Boxman et al., 2008; Engardt et al., 2017; Prechtel et al., 2001), nitrogen inputs remain in many cases elevated (Boxman et al., 2008; Vuorenmaa et al., 2017) and (iv) forest endure today increased pressure due to the intensification of silvicultural practices and harvesting (Achat et al., 2015; Bouvet et al., 2019; De Turckheim, 1990; Paré and Thiffault, 2016). The current context of global and climate change may encourage tree species conversions in order to adapt forest stands to the changing climate and/or increase forest productivity (Bolte et al., 2009; Thurm et al., 2018).

The common garden experiment of the Breuil-Chenue site (Burgundy, France), installed in 1976 and monitored since 2001 (see details in material and methods section), is a fairly unique experiment that compares 6 monospecific plots: oak (Quercus sessiliflora Smith.), beech (Fagus sylvatica L.), Norway spruce (Picea abies Karst.), Douglas fir (Pseudotsuga menziesii Mirb. Franco.), Nordmann fir (Abies nordmanniana Spach.) and Laricio pine (Pinus nigra Arn. ssp laricio Poiret var corsicana) Based upon soil sampled in 2001, Mareschal et al., (2010) showed that tree species had an impact on the chemical properties of the topsoil 25 years after plantation and variations of cationic exchange capacity and soil $\mathrm{pH}$ between the different stands were partly controlled by the carbon content of the soil. Thereafter, numerous fluxes and processes have been shown to differ between the different tree species plots. Tree species strongly influence soil carbon stocks and mineralization (Trum et al., 2011). The rate of organic matter decomposition in the different stands was Norway spruce $>$ Native forest $>$ Beech $>$ Douglas fir and larger amounts of dissolved organic carbon (organic acids) were released into the solution leaching the humus layer in the Norway spruce stand (Moukoumi et al., 2006). Nitrification was shown to also be a very important factor differentiating trees species: highest under Douglas fir, Laricio pine, beech and oak (Andrianarisoa et al., 2010; Legout et al., 2016; Moukoumi et al., 2006; Trum et al., 2011; Zeller et al., 2007). For Douglas fir and Laricio pine, nitrate concentrations dominated the total anion charge in soil solutions and led to greater leaching fluxes of Al, Ca, Mg and K (Legout et al., 2016).

The goal of this study is to investigate the consequences of these different processes and fluxes on the chemical fertility of the soil 45 years after the plantation of the monospecific stands. The detailed objectives of the present study are (i) quantify the change of soil chemical fertility and the effect of tree species over the 45 years after plantation and, (ii) try to integrate these results in a more global approach to evaluate tree species effect based on several criterions (soil fertility, water quality, wood production...). For this, we studied the humus layer, mineral soil layers down to $70 \mathrm{~cm}$ depth from samples collected in 1974, 2001 and 2019 in the 6 monospecific stands of the Breuil-Chenue experimental site. Based on the previously cited studies (Legout et al., 2016; Mareschal et al., 2010; Moukoumi et al., 2006; Zeller et al., 2007), we hypothesize that chemical fertility degradation occur as follow: (i) elevated in the Douglas fir 
and Laricio pine, due mainly to acidolysis related to high nitrification rate and nutrient cation leaching, (ii) intermediate in the Nordman fir, Norway spruce and oak due to acidolysis and chelation (in relation to the release of organic acids from organic matter transformation) and (iii) less intense in the beech plot.

\section{Methods}

\subsection{Experimental site}

The experimental site of Breuil-Chenue is located in the Breuil-Chenue state forest in the Morvan Regional Natural Park, Burgundy, France (latitude $4^{\circ} 18^{\prime} 10^{\prime}$, longitude $4^{\circ} 4^{\prime} 44^{\prime}$ ) at $640 \mathrm{~m}$ elevation. The annual rainfall is on average $1180 \mathrm{~mm}$ and the annual temperature $9^{\circ} \mathrm{C}$ (over the period 2006-2012). In 1975, the native forest (coppice with standards (CWS) composed of beech and oak) located on a homogeneous soil type was clear-cut. The organic layer and harvest residues were removed with a bulldozer. Monospecific plots ( $1000 \mathrm{~m}^{2}$ each) of oak (Quercus sessiliflora Smith.), beech (Fagus sylvatica L.), Norway spruce (Picea abies Karst.), Douglas fir (Pseudotsuga menziesii Mirb. Franco.), Nordmann fir (Abies nordmanniana Spach.) and Laricio pine (Pinus nigra Arn. ssp laricio Poiret var corsicana) were planted and a plot of native forest was left unharvested (Fig. 1). This study focuses on the unfertilized plots of the block 1 . The chemical properties of the soil are described in Supplementary material 1.

The soil is developed on the "La Pierre qui Vire" leucogranite the composition of which is poor in $\mathrm{Mg}, \mathrm{K}$ and particularly $\mathrm{Ca}$. The deep soil $(70-90 \mathrm{~cm})$ contains $67.32 \%$ of $\mathrm{SiO}_{2}, 21.82 \%$ of $\mathrm{Al}_{2} \mathrm{O}_{3}, 2.86 \%$ of $\mathrm{Fe}_{2} \mathrm{O}_{3}$, $0.1 \%$ of $\mathrm{MnO}, 0.42 \%$ of $\mathrm{MgO},<0.02 \%$ of $\mathrm{CaO}, 1.54 \%$ of $\mathrm{Na}_{2} \mathrm{O}, 4.90 \%$ of $\mathrm{K}_{2} \mathrm{O}, 0.31 \%$ of $\mathrm{TiO}_{2}$ and $0.10 \%$ of $\mathrm{P}_{2} \mathrm{O}_{5}$ (van der Heijden et al., 2013). The soil is an Alumic Cambisol (WRB FAO) close to cryptopodzolization in the upper horizons (Ranger et al., 2004). The soil is acidic and nutrient poor with a saturation rate below $10 \%$ in the A horizon in the native forest plot (Mareschal et al., 2013). The humus type in all plots is a mesomull (Brêthes et al., 1995) with a layer $L$ and $F$ for all species except in the native forest plot where the humus type is a moder (Moukoumi et al., 2006).

The silvicultural management of the different plots followed the regional guidelines, forest planning and management practices defined by the French National Forest Office (ONF). No thinnings occurred during the first 24 years. From 2000 onwards, thinnings occurred approximately every 7 years for the coniferous plots and every 9 or 10 years for hardwood plots. All above ground biomass of thinned trees was exported. The thinnings were carried out manually (i.e. no mechanization of felling, logging or skidding) as follows (Legout et al., 2016):

- November 2000: 1 st thinning of the Norway spruce (30\% removed) and Douglas fir (43\% removed) stands.

- November 2001: 1 st thinning of the beech (48\% removed), oak (14\% removed), Nordmann fir (15\% removed) and Laricio pine (10\% removed) stands.

- March 2007: 2nd thinning of the Norway spruce (24\% removed) and Douglas fir (36\% removed) stands. 
- November 2008: 2nd thinning of the oak (7\% removed), Nordmann fir (35\% removed) and Laricio pine $(27 \%$ removed) stands.

- January 2014: 2nd thinning of the beech (36\% removed) stand.

- An additional thinning for the plots of Norway spruce (15\% removed), Nordmann fir (10\% removed) and Douglas fir (15\% removed) was carried out in the fall of 2016.

\subsection{Soil and organic layer sampling and analysis}

In 1974, soil samples were collected at 7 systematic depths: 0-10, 10-20, 20-30, 30-40, 40-50, 50-60 and $70-80 \mathrm{~cm}$. 8 replicate soil profiles were sampled. Exchangeable $\mathrm{Ca}, \mathrm{Mg}$ and $\mathrm{K}$ were extracted on a percolation column with buffered ammonium acetate at $\mathrm{pH}=7$ ( $25 \mathrm{~g}$ fine earth and $200 \mathrm{~mL}$ ammonium acetate solution at $1.5{\mathrm{~g} . \mathrm{L}^{-1}}^{-1}$ ) (Duchaufour, 1970) and dosed by ICP-AAS. The density of fine earth was measured with a cylinder of $503 \mathrm{~cm}^{3}$.

In 2001 and 2019, soil samples were collected with a cylindrical auger at 7 systematic depths: 0-5, 5-10, $10-15,15-25,25-40,40-55$ and 55-70 cm. For each plot, 16 soil profiles were collected in 2001 and 5 in 2019. The samples were air-dried, grinded and sieved $(2 \mathrm{~mm})$. The organic layer (OI, Of and Oh) was collected directly above the mineral soil sample profile using a $0.1 \mathrm{~m}^{2}$ quadrat and dried at $65^{\circ} \mathrm{C}$ to constant weight. In 2001, the organic layer dry mass was measured for all replicates but its chemical composition was only measured for 8 of the 16 replicates. In 2019, all samples were weighed and analyzed. $\mathrm{N}$ and $\mathrm{C}$ concentrations in the organic layer were determined in 2001 and 2019 by an elemental analyzer, while $\mathrm{K}, \mathrm{Ca}, \mathrm{Mg}, \mathrm{P}$ were determined by ICP-AES after a nitric acid digestion.

In 2001, the density of fine earth was measured for each stand and horizon. The texture was measured for each stand and each depth of four profiles. The $\mathrm{pH}$ water and $\mathrm{pH} \mathrm{KCl}$ of soil samples were measured using a Mettler pH meter TSDL25 after 12 hours of contact with respectively distilled water and a 1 mol.L' 1 solution of $\mathrm{KCl}$ (soil/solution ratio: 1/5). The exchangeable pools of $\mathrm{Mg}^{2+}, \mathrm{Ca}^{2+}, \mathrm{Na}^{+}, \mathrm{Fe}^{3+}, \mathrm{Al}^{3+}$, and $\mathrm{Mn}^{2+}$ were determined from two sequential soil extractions using a $1 \mathrm{~mol}^{-1} \mathrm{~L}^{-1} \mathrm{KCl}$ reagent. The exchangeable pools of $\mathrm{K}^{+}$were determined from two sequential soil extractions using a 1 mol.L ${ }^{-1} \mathrm{NH}_{4} \mathrm{Cl}$ reagent (Espiau and Peyronel, 1976). Extracted solutions were dosed by ICP-AES (JY180 ULTRACE, Horiba Jobin Yvon, Longjumeau, France). $\mathrm{H}^{+}$ions were extracted with a solution of $\mathrm{KCl} 1 \mathrm{~mol}^{-\mathrm{L}^{-1}}$ and titrated with an automatic titrimeter (Mettler TS2DL25) (Rouiller et al., 1980). Concentrations of $C$ and nitrogen $(\mathrm{N})$ were determined by elemental analysis from a test sample of $0.5 \mathrm{~g}$ and $1 \mathrm{~g}$ soil, respectively (Anne method (1945) and Kjeldahl method). Poorly crystalized and amorphous aluminium (hydr)oxides were extracted by a Tamura extraction (Tamura, 1958) $(0.5 \mathrm{~g}$ of soil in $40 \mathrm{~mL}$ of sodium tricitrate reagent at $1 \mathrm{M}, \mathrm{pH}=7.3$ ) and analyzed by ICP-AES (Jobin-Yvon Instruments, Longjumeau, France, model JY 180) (Mareschal, 2008).

In 2019, the chemical properties of soil samples were obtained by analyses at the INRAE-Arras laboratory: $\mathrm{pH}$ water (soil water $\mathrm{pH}-1: 5$ soil to water volume ratio) and $\mathrm{pH} \mathrm{KCl}$ (soil $\mathrm{KCl} \mathrm{pH}-1: 5$ soil to $0.1 \mathrm{~mol} \mathrm{~L}^{-1}$ $\mathrm{KCl}$ reagent volume ratio) (NF ISO 10390), C and N content, cationic exchange capacity and 
exchangeable pools ( $\mathrm{Mg}, \mathrm{Ca}, \mathrm{K}, \mathrm{Na}, \mathrm{Al}, \mathrm{H}$, and $\mathrm{Mn}$ ) extracted with a cobaltihexamine reagent $(5 \mathrm{~g}$ of soil in a $100 \mathrm{~mL}$ of $\mathrm{Co}\left(\mathrm{NH}_{3}\right)_{6}{ }^{3+}$ solution at $1 \mathrm{molc}^{-1} \mathrm{~L}^{-1}$ ) (NF X 31-130). Tamura extraction (same protocol applied as in 2001) were carried out at the INRAE BEF laboratory and dosed by ICP-AES (Agilent 7500series). Though cobaltihexamine, $\mathrm{KCl}$ and $\mathrm{NH}_{4} \mathrm{Cl}$ molc. $\mathrm{L}^{-1}$ extractions showed similar results (Ciesielski et al., 1997a, b), we carried out a comparison between these methods: a subset of 48 samples (2019 campaign) was randomly selected and no significant differences were observed between extraction methods for $\mathrm{Ca}, \mathrm{Mg}$ and $\mathrm{K}$ ( $\mathrm{p}$-value $<0.001)$.

The exchange acidity (EA) is defined as the sum of $\mathrm{H}^{+}$and $\mathrm{Al}^{3+}$, the $\mathrm{CEC}$ as the sum of the exchangeable cations $\left(\mathrm{Mg}^{2+}, \mathrm{Ca}^{2+}, \mathrm{Na}^{+}, \mathrm{K}^{+}, \mathrm{Fe}^{3+}, \mathrm{Mn}^{2+}, \mathrm{H}^{+}, \mathrm{Al}^{3+}\right)$ and the sum of basic exchangeable cations (S) as the sum of $\mathrm{Mg}^{2+}, \mathrm{Ca}^{2+}$ and $\mathrm{K}^{+}$.

\subsection{Correction of the organic layer thickness sampling bias}

Correctly separating the organic layer from the mineral topsoil layer is very complex and may lead to an important overestimation of the organic layer mass. The loss on ignition (LOI) was measured for organic layer samples collected in 2001 and 2019 (for 2001, 5 samples were randomly selected) to check for possible bias between campaigns. The organic layer was sieved $(<0.2 \mathrm{~mm})$, oven-dried at $105^{\circ} \mathrm{C}$ for a minimum of 24 hours and then heated in the mitten oven (Herrmann Moritz West 2050) following a temperature increase ramp: the temperature was gradually increased by 100 degrees over 20 minutes and maintained stable for 30 minutes. This sequence was repeated until the temperature reached $500^{\circ} \mathrm{C}$. Then, the samples were maintained at $500^{\circ} \mathrm{C}$ for 4 hours. LOI data showed that the 2001 organic layer samples contained a substantial amount of mineral material.

The organic layer dry weight in 2001 was thus corrected ( $\left.D W_{\text {corrected }}\right)$ for the sampling bias by assuming that the LOI in the 2001 samples should be equal to the LOI measured in 2019 as follows (Eq. 1) (Supplementary material 2) :

(Eq .1) $D W_{\text {corrected }}=D W_{\text {uncorrected }} \times\left[1-\left(1-\frac{L I_{2001}}{L O I_{2019}}\right)\right]$

We estimated that the excess dry mass measured in the organic layer in 2001 was caused by a $0-5 \mathrm{~cm}$ organo-mineral soil layer inclusion of less than one millimetre of thickness. No correction on soil stocks was applied because i) this soil thickness was very small compared to the sampled $0-5 \mathrm{~cm}$ layer and ii) the estimated $\mathrm{Mg}, \mathrm{Ca}$ and $\mathrm{K}$ pools in a millimetre thick layer were much smaller than the $\mathrm{Ca}, \mathrm{Mg}$ and $\mathrm{K}$ pool correction in the organic layer.

\subsection{Quantification limits and date outliers}

We chose to replace values in the dataset that were below the analytical quantification limit by the quantification limit value. Changes in quantification limits can result in a considerable bias (Hansson et al., 2020). In order to avoid such biases, i) quantification limit values were set to the highest value between the 2001 and 2019 campaign and ii) we replaced the values below the analytical quantification 
limit by the quantification limit values. These changes affected $9.4 \%, 0.2 \%, 15.4 \%, 55.6 \%$ and $1.4 \%$ of the exchangeable $\mathrm{Fe}, \mathrm{Mg}, \mathrm{Ca}, \mathrm{Na}$ and $\mathrm{H}$ values in the initial dataset.

Potential outliers were identified based on the distributions of each measured variable. Outliers were identified if they were outside the boundaries A (Eq. 2) and B (Eq. 3) defined as:

(Eq. 2) $A_{x, y}=Q_{x, y}(25 \%)-2.5 \times I Q_{x, y}$

(Eq. 3) $B_{x, y}=Q_{x, y}(75 \%)+2.5 \times I Q_{x, y}$

where $A_{x, y}$ and $B_{x, y}$ are the criteria below and above which concentrations of element $x$ are considered abnormally low or high in soil y; $Q_{x, y}(25 \%)$ is the $25 \%$ quantile of element $\mathrm{x}$ in soil y ; $Q_{x, y}(75 \%)$ is the $75 \%$ quantile of element $\mathrm{x}$ in soil $\mathrm{y} ; I Q_{x, y}$ is the interquantile of element $\mathrm{x}$ in soil $\mathrm{y}$.

No organic layer data and no 2019 mineral soil data were removed.

\subsection{Pool size calculation methodology}

As described previously, fine earth bulk density was measured in 1974 and 2001 but not in 2019 .

An average of fine earth density measured in 1974 was calculated for each sampled soil layer.

A statistical test (ANOVA) on bulk density was carried out and no significant difference between the plots was observed between in 2001 (Tukey test; pvalue >0.05). We therefore assumed that fine earth bulk density was constant between 2001 and 2019. The average fine earth bulk density was calculated for each stand and each sampled soil layer from the 2001 data. The pools of nutrients in the soil in 2001 and 2019 were calculated from the averaged stand fine earth bulk density.

For comparison, stocks in equivalent soil layers were calculated for the 1974 soil profile to match those of 2001 and 2019.

\subsection{Statistical tests}

In order to test differences between tree species stands for each depth and for both dates (2001 and 2019), an ANOVA and a Tukey test were performed with a $5 \%$ level of significance. The differences between both sampling dates for each stand were tested with a Student test when the data followed a normal distribution (Shapiro test) with a significance of $p$-value $<0.05$ or 0.1 or with a Wilcoxon test when the data failed the normal distribution test. Though the design of this experiment didn't include replicated blocks (simple pseudoreplication according to Hurlbert (2004)), the comparison of the different tree species plots is nevertheless valuable to understand tree species effects on soil chemical fertility (Davies and Gray, 2015). Moreover, a detailed study of the Breuil site showed that the soil under these different tree species is comparable (Ranger et al., 2004). What is more, each individual tree species plot of this common garden experiment covers a large surface $\left(1000 \mathrm{~m}^{2}\right)$ given them a strong spatial representativeness in contrast to a "classic block experiment" where the plots may be much smaller. 
Correlation between different data series were tested with Pearson (data followed a normal distribution) or Kendall (data not followed a normal distribution) tests with a significance of $p$-value $<0.05$.

Monte-Carlo simulations were carried out to estimate uncertainties associated with the differences in soil chemical properties or nutrient pools between 2019 and 2001 (noted $\Delta_{2019-2001}$ ). For each variable, an average value was calculated for both 2001 and 2019 by randomly selecting values within a normal distribution defined from the measured average and stand deviation of the variable in 2001 and 2019. The $\Delta_{2019-2001}$ value was then calculated. This calculation procedure was repeated to generate a population ( $n=1000)$ of $\Delta_{2019-2001}$ values and the standard deviation of this population was calculated. Two $\Delta_{2019-2001}$ values were considered significantly different when the difference was greater than the sum of both standard deviations (i.e. no standard deviation overlap).

\subsection{Multi-criteria approach}

Be interested in only chemical parameters is not enough to judge the tree species effect. A multi-criteria approach was established to better compare the tree species at the ecosystem scale by including soil chemical fertility criteria as well as other ecosystem compartments and functions. For this approach, the following criteria were considered:

- the variation of the pools of exchangeable nutrient cations in soil $(0-70 \mathrm{~cm})$ between 2001 and 2019 (\% loss or gain in $\mathrm{Ca}^{2+}, \mathrm{Mg}^{2+}$ and $\mathrm{K}^{+}$)

- the variation of $\mathrm{Ca}, \mathrm{Mg}$ and $\mathrm{K}$ pools in organic layer over the same period

- the variation of soil acidity measured by $\mathrm{pH}_{\mathrm{KCl}}$ and the soil exchange acidity averaged over the 0 $70 \mathrm{~cm}$ profile (in \% of evolution) between 2001 and 2019

- the variation of the soil CEC cumulated over the $0-70 \mathrm{~cm}$ profile

- the aboveground biomass production averaged over the 1976 to 2019 period (trunk biomass (wood and bark) with a diameter greater than $7 \mathrm{~cm}$ ) obtained by allometric equation (Supplementary material 3)

- the soil fungal diversity (number of fungal species (Buée et al., 2011))

- the quality of the water draining the soil profile assessed by the concentration of $\mathrm{NO}_{3}{ }^{-}$and $\mathrm{Al}^{3+}$ in the soil solution. An individual score based on the amount of $\mathrm{NO}_{3}{ }^{-}$and $\mathrm{Al}^{3+}$ was established from the article by (Legout et al., 2016). An average of these two scores was then established.

For comparison, each criteria was translated into a score ranging from 1 to 7,7 corresponding to the "best observed condition" for each criteria (Supplementary material 4).

\section{Results}

\subsection{Pool size change in the mineral soil}


Over the 1974-2001 period, the stocks of exchangeable Mg in the soil decreased strongly in all the stands: an average net loss of $148 \mathrm{~kg}_{\text {.ha }}{ }^{-1}$ and a maximal loss of $156 \mathrm{~kg}^{-\mathrm{ha}^{-1}}$ in the Nordmann fir stand (Fig. 2). The strongest decrease in exchangeable $\mathrm{Ca}$ and $\mathrm{K}$ pools (respectively $-63 \mathrm{~kg} \mathrm{ha}^{-1}$ and $-45 \mathrm{~kg}^{-\mathrm{ha}^{-1}}$ ) was also observed for the Nordmann fir stand. For the other stands, soil exchangeable Ca pools only slightly decreased whereas exchangeable $\mathrm{K}$ pools increased in the Norway spruce, Douglas fir and oak stands by respectively $+47,+15$ and $+124 \mathrm{~kg} \mathrm{ha}^{-1}$.

Between 2001 and 2019, soil exchangeable Ca and Mg pools increased in all stands except for Mg in the beech stand $\left(-4 \mathrm{~kg} \mathrm{ha}^{-1}\right)$ but these trends were not all statistically significant (Tab. 1). Differences between tree species were small in 2001 for both $\mathrm{Ca}$ and $\mathrm{Mg}$ and only the CWS and Douglas fir plots differed from the other species. The largest losses in the soil were observed for the exchangeable $\mathrm{K}$ pool and the exchangeable pools of $\mathrm{K}$ decreased significantly for all stands except the CwS and Nordman fir stands. For this nutrient, the largest decrease between 2001 and 2019 was recorded in the oak stand $\left(-182 \mathrm{~kg} \mathrm{ha}^{-1}\right)$. In the Nordmann fir stand, the exchangeable K pool remained stable $\left(+4 \mathrm{~kg}^{\mathrm{h}} \mathrm{ha}^{-1}\right)$. Large differences between tree species were observed in 2001. The exchangeable K pool in 2001 was largest in the Nordmann fir and Norway spruce stands mainly due to the elevated exchangeable $\mathrm{K}$ pools in the topsoil layers $(0-5 \mathrm{~cm})$. No significant differences between tree species were observed in 2019 .

The nitrogen pool in the $0-40 \mathrm{~cm}$ of the soil profile increased between 2001 and 2019 in all stands (Supplementary material 1 ) mainly in the $0-15 \mathrm{~cm}$ soil layer. The $\mathrm{C}: \mathrm{N}$ ratio in the $0-40 \mathrm{~cm}$ layer decreased over the same period for all stands except for the Nordmann fir (in surface) and the beech for which it increased (Supplementary material 1).

\subsection{Pool size change in the organic layer between 2001 and 2019}

In the organic layer, the variations of nutrient pool sizes were very variable depending on the nutrient and the tree species. The pools of $\mathrm{Ca}, \mathrm{Mg}$ and $\mathrm{K}$ increased in the $\mathrm{CWS}$, Douglas and Nordmann fir stands but decreased in the Laricio pine and oak stands. The largest loss of nutrients was observed in the Laricio pine stand with $-13.6 \mathrm{~kg} . \mathrm{ha}^{-1}$ of $\mathrm{Ca},-7.3 \mathrm{~kg} \cdot \mathrm{ha}^{-1}$ of $\mathrm{Mg}$ and $-11.5 \mathrm{~kg} \cdot \mathrm{ha}^{-1}$ of $\mathrm{K}$. The Ca pool remained stable in the beech stand. In the Norway spruce stand, the Ca pool increased but the $\mathrm{Mg}$ and $\mathrm{K}$ pools decreased. Differences between tree species were more significant in 2019 compared to 2001.

The change in nutrient pool sizes in the organic layer is partially explained by the decrease in organic layer dry weight observed in all stands except for the Nordmann fir and CWS stands in which it increased. The decrease in organic layer dry weight in the Douglas fir stand was smaller than in the other stands and was not statistically significant (Supplementary material 5). Differences between tree species were larger in 2019 compared to 2001 and more pronounced in the organic layer compared to the mineral soil.

\subsection{Soil chemical property change over time}


Even though few differences (between tree species and between sampling dates) were significant at the soil layer scale (Fig. 3, Fig. 4, Fig. 5 and Fig. 6), similar behaviors were observed. The oak and the beech showed similar behaviors: the $\mathrm{pH}_{\mathrm{KCl}}$ in these two stands increased over time and over the entire soil profile while the exchangeable acidity (EA), the sum (S) of nutrient cations $(\mathrm{Ca}+\mathrm{Mg}+\mathrm{K})$ and the CEC decreased (Fig. 3, Fig. 4, Fig. 5 and Fig. 6). The Nordmann fir, Norway spruce and CwS stands also showed similar behaviors: the CEC, EA and S increased in the topsoil layers and decreased or remained stable in the deeper soil layers. The behavior of the Douglas fir and Laricio pine stands was intermediary compared to the Nordmann fir/Norway spruce/CwS and oak/beech. The EA and CEC in the Douglas fir and Laricio pine stands increased in the topsoil layers and soil $\mathrm{pH}_{\mathrm{KCl}}$ decreased but less remarkably than in the Nordmann fir, Norway spruce and CwS stands (Fig. 3). The general behavior of the Douglas fir was closer to that of the Nordmann fir, Norway spruce and CwS stands whereas the behavior of the Laricio pine was closer to that of the oak and beech stands (the Laricio pine stand differed from the oak and beech stands only in the $0-5 \mathrm{~cm}$ soil layer).

Soil carbon content increased significantly in the $0-10 \mathrm{~cm}$ for all tree species except for the oak and beech stands for which the increase was not significant. The increase in carbon occurs mainly in the $0-5 \mathrm{~cm}$ horizons and weaker over 5-10 cm (Fig. 7).

\subsection{Correlations between different soil chemical properties}

In the soil layers down to $15 \mathrm{~cm}$, the variations of $S$ and CEC between 2001 and 2019 were positively related to the variations of soil carbon content (Fig. 8E).

The relation between the variations of $\mathrm{S}(\Delta \mathrm{S})$ and the variations of soil $\mathrm{pH}_{\mathrm{KCl}}\left(\Delta \mathrm{pH}_{\mathrm{KCl}}\right)(\mathrm{p}$-value $<0.05)$ (Fig. 8D) shows that, in the deeper soil layers, when $\mathrm{pH}_{\mathrm{KCl}}$ increases $\mathrm{S}$ slightly increases but that $\mathrm{S}$ is stable or decreased in the 0-15 cm soil layers for the beech and oak stands despite an increase in $\mathrm{pH}_{\mathrm{KCl}}$. The variations in exchange acidity $(E A)$ was positively related to the variations of $S$ with a correlation coefficient of 0.71 ( $p$-value $<0.05$ ) (Fig. 8A) but this relation was mainly supported by the variations in the $0-15 \mathrm{~cm}$ soil layers of the Norway spruce, Douglas fir, Nordmann fir and CwS stands. EA decreased for all soil layers below $15 \mathrm{~cm}$ depth in all the stands and in the $0-15 \mathrm{~cm}$ layers in the beech and oak stands. As EA decreased, $S$ remained stable in the deeper soil layers of the coniferous stands and decreased in the topsoil layers in the beech and oak stands. The variations of CEC were negatively correlated to the variations of soil $\mathrm{pH}_{\mathrm{KCl}}$ ( $\mathrm{p}$-value $\left.<0.001\right)$, positively correlated to the variations of exchangeable $\mathrm{Al}$ ( $\mathrm{p}$ value < 0.001) (Fig. 8C, Fig. 9D), and negatively correlated to the variations in Tamura-extractible Al content for the topsoil layers but not for the deeper soil layers (Fig. 8B).

Observing the exchangeable cations individually (Fig. 9) showed that as the variations in exchangeable K were strongly correlated to the variations of the CEC (correlation coefficient of 0.75 , p-value < 0.05 ) whereas exchangeable $\mathrm{Mg}$ and Ca remained relatively stable despite the CEC decrease (except for the exchangeable $\mathrm{Ca}$ in the beech and oak stands). The oak and beech stands differed from the general trend in the topsoil layers $(0-15 \mathrm{~cm})$ for both exchangeable Ca and Al. 


\subsection{Multi-criteria approach}

For most criteria, the CwS plot was among the best graded plots: fungal biodiversity, chemical quality of draining water and temporal change in plant-available nutrient cations ( $\mathrm{Ca}, \mathrm{Mg}$ and $\mathrm{K}$ ). This suggests that a certain balance between the different ecosystem functions has taken place in this stand. However, the CwS plot had poor grades for the criteria assessing the change over time of soil $\mathrm{CEC}, \mathrm{pH}_{\mathrm{KCl}}$ and exchangeable acidity (Fig. 10). The oak and beech plots had the best grades for the criteria assessing the change over time of soil pH and exchangeable acidity in the $0-70 \mathrm{~cm}$ soil profile. The coniferous stands had the highest grades for the criteria assessing the change over time of soil CEC. The Douglas fir and to a lesser extent the Norway spruce and Laricio pine stands displayed a much higher biomass production compared to the beech and oak stands. However, the Douglas fir and Laricio pine stands had the lowest grades for the criteria assessing the chemical quality of draining waters and the fungal biodiversity (Fig. 10).

\section{Discussion}

\subsection{Contrasting signs of soil recovery from past acidification}

\subsubsection{Chemical fertility change in the mineral soil between 1974 and 2001}

It is difficult to decisively conclude on the exchangeable $\mathrm{Ca}, \mathrm{Mg}$ and $\mathrm{K}$ pool size change between 1974 and 2001 because the soil sampling and analytical methods are never strictly comparable. However, the very small differences observed between both dates for the exchangeable $\mathrm{Ca}$ and $\mathrm{K}$ pools strongly suggest that the reservoirs of these nutrients remained stable. In the same time, exchangeable $\mathrm{Mg}$ pools decreased very strongly (Fig. 2). As discussed in a previous study (van der Heijden et al., 2013), this net loss of $\mathrm{Mg}$ is most likely explained by elevated $\mathrm{Mg}$ leaching in the first years following the clear cut in 1975 when the site was setup caused by a rapid increase in the organic matter decomposition after the opening of the canopy (Dahlgren and Driscoll, 1994; Legout et al., 2009; Vitousek et al., 1979). Ca was probably better retained in the soil profile due to its greater affinity for organic cation exchange and adsorption sites compared to $\mathrm{Mg}$ and K (van der Heijden et al., 2014). The different behaviors could also be explained by the different relative abundances of $\mathrm{Mg}, \mathrm{Ca}$ and $\mathrm{K}$ on the CEC in 1974. Mg occupied a greater proportion of the CEC in 1974 compared to $\mathrm{Ca}$ and $\mathrm{K}$ and may thus have been more easily available. The exchangeable $\mathrm{Mg} / \mathrm{Ca}$ and $\mathrm{Mg} / \mathrm{K}$ ratios averaged over the $0-70 \mathrm{~cm}$ soil profile were respectively 2.1 and 1.6 in 1974 (Supplementary material 6).

One might have also expected the exchangeable K pools to decrease between 1974 and 2001 but they remained stable and in certain stands slightly increased. It is possible that the $\mathrm{K}$ weathering flux over the 1974-2001 period may have compensated for net losses in the water drainage flux. Indeed, in the beech 
plot, the K-mineral weathering flux estimated for the 2002-2008 period was 6 fold greater than the $\mathrm{Mg}$ weathering flux (respectively 2.9 and $0.5 \mathrm{~kg} \cdot \mathrm{ha}^{-1}$ ) (van der Heijden et al., 2013). The amount of acid atmospheric deposition during the 1974-2001 period was also probably greater than over 2002-2008 which would probably have enhanced the mineral weathering in the soil. Finally, specific K exchange sites in the interfoliar space of phyllosilicates may also have contributed to better retaining $\mathrm{K}$ in the soil compared to Mg (Poonia and Niederbudde, 1990).

\subsubsection{Chemical fertility change in the mineral soil between 2001 and 2019}

The change in a certain number of soil properties between 2001 and 2019 suggests that the soil chemical fertility is slowly recovering from past acidification. Indeed for most stands, the exchangeable $\mathrm{Ca}$ and $\mathrm{Mg}$ pools in the $0-70 \mathrm{~cm}$ soil profile increased (even if not always significantly) (Fig. 2) and the soil pH (pH $\mathrm{H}_{20} \mathrm{O}$ et $\mathrm{pH}_{\mathrm{KCl}}$ ) increased in the soil layers deeper than $15 \mathrm{~cm}$ for all stands (Fig. 3 and Supplementary material 1). However, many other soil properties indicated an on-going acidification and a degradation of soil chemical fertility. Indeed, except for the oak and beech stands, the soil pH decreased in the topsoil layers (Fig. 3 and Supplementary material 1). Moreover, the exchangeable pools of $K$ in the $0-70 \mathrm{~cm}$ soil profile decrease in all stands except for the Nordmann fir stand (Fig. 2). Finally, the cationic exchange capacity in the $0-70 \mathrm{~cm}$ soil profile decreased for all stands (Supplementary material 1) despite the observed increase in CEC in the $0-15 \mathrm{~cm}$ soil layers in the Douglas fir, Norway spruce and Nordmann fir stands.

These results illustrated the necessity to study and compare different soil indicators to correctly assess the evolution of soil chemical fertility and also showed that tree species effect must be taken into account. Even if compensation may occur at the scale of the soil profile $(0-70 \mathrm{~cm})$, tree species effect is more pronounced in the topsoil layers, as pointed out by other studies (Augusto et al., 2002).

\section{Soil cationic exchange capacity change}

The change in CEC likely played a major role in the temporal changes observed in the different tree species plots. Several causes may have led to these CEC changes in the different stand and soil layers. These changes cannot be explained by a change in the contribution of CEC variable charges (activation or deactivation of exchange sites) because the variations in CEC were negatively correlated to the variations in soil pH (Fig. $8 \mathrm{C}$ ). The dynamics of the CEC may be, at least partially, explained by the dynamics of the soil carbon pool (Fig. 8E). Indeed, a large proportion of the total CEC originates from organic cationic exchange sites (Mareschal et al., 2010; van der Heijden et al., 2014), and, for the coniferous (Norway spruce, Nordmann fir, Douglas fir) and CWS stands, the increase in soil CEC was related to the increase in carbon content in the $0-15 \mathrm{~cm}$ soil layers (Fig. $8 \mathrm{E}$ ). The dynamics of carbon cannot, however, account alone for the observed CEC changes because (i) the soil carbon content increased in the topsoil but not or very little in depth (no significant differences) (Fig. 7 and Fig. 8E), (ii) for the beech and oak stands, the carbon content increased in the topsoil but the CEC decreased (Fig. 6 , 
Fig. 7 and Fig. 8E), and (iii) although the CEC and carbon content were positively correlated in 2001 (Mareschal et al., 2010) and 2019, the slope of the relation was different in 2019 (data not shown).

Mareschal et al., (2013) demonstrated a strong relation between the CEC and the precipitation/dissolution of aluminium hydroxides in the interfoliar space of phyllosilicates at the Breuil site: the precipitation of Al hydroxides blocks the accessibility of cationic exchange sites thus reducing the CEC. These mechanisms probably greatly contribute to explaining the observed dynamics of the CEC between 2001 and 2019 in all the stands. The negative correlation between the CEC variations and the variations of Tamura extracted Al content (Fig. 8B) and the negative relationships between Tamura extracted Al and the CEC (Fig. 11) in 2001 and 2019 support this hypothesis.

This hypothesis enables to explain the surprising negative correlation found between the variation of soil $\mathrm{pH}$ and the variation of CEC (Fig. $8 \mathrm{C}$ ): as the $\mathrm{pH}$ increases, Al solubility decreases causing the precipitation of Al hydroxides in the phyllosilicate interfoliar space as suggested by Mareschal et al., (2013); conversely, as the $\mathrm{pH}$ decreases, Al solubility increases and favoring the dissolution of interfoliar Al hydroxides.

\section{Consequences for the nutrient cations}

The dissolution and precipitation of interfoliar Al hydroxides may impact more severely the exchangeable pools of $\mathrm{K}$ because the freed or blocked sites by interfoliar Al hydroxides are likely to be more frequently specific K exchange site (interfoliar sites) (Mareschal et al., 2009). Our results showed a positive correlation between the variations of the CEC and exchangeable K pools (Fig. $9 \mathrm{C}$ and Supplementary material 1) but no relation between on the one hand the variations of the CEC and on the other hand the variations of the exchangeable $\mathrm{Mg}$ and Ca pools. This suggests that the precipitation of interfoliar $\mathrm{Al}$ hydroxides during the 2001-2019 period caused a net desorption flux of $\mathrm{K}$ from the interfoliar space of phyllosilicates and would explain the decrease in exchangeable $\mathrm{K}$ pools over this period for almost all studied tree species. The dynamics of Al are most likely the main driver of the variations of exchangeable nutrient cations in the soil of the different tree species over the 2001-2019 period.

$\mathrm{Mg}$ and $\mathrm{Ca}$ exchangeable pools were less affected by $\mathrm{CEC}$ variations than exchangeable $\mathrm{K}$ pools except in the topsoil of the oak and beech stands (Fig. 9A and Fig. 9B). This could be explained by the fact that potassium is mainly adsorbed on the mineral fraction of the CEC (Poonia and Niederbudde, 1990; van der Heijden et al., 2014), notably on exchange sites specific to $\mathrm{K}$ as previously discussed. $\mathrm{Mg}$ and $\mathrm{Ca}$ are adsorbed on both the mineral and organic fraction of the CEC. What is more, the exchangeable Ca pool variations in the $0-70 \mathrm{~cm}$ soil profile were correlated to the variations of the Ca pool in the organic layer (data not shown) but no such relation was found for $\mathrm{Mg}$ and $\mathrm{K}$. This relation suggests that $\mathrm{Ca}$ accumulated in the soil through the biological cycle and was retained more strongly in the mineral soil compared to $\mathrm{Mg}$ and $\mathrm{K}$ due to Ca higher affinity for organic cationic exchange sites (DeSutter et al., 2006; van der Heijden et al., 2014). The different behavior of $\mathrm{K}$ compared to $\mathrm{Mg}$ and Ca could also be due to the smaller exchangeable pools of $\mathrm{Ca}$ and $\mathrm{Mg}$ in 2001 compared to $\mathrm{K}$ (the average pools for all tree species 
were respectively 54,33 et $293 \mathrm{~kg} \cdot \mathrm{ha}^{-1}$ ). The lower availability of $\mathrm{Mg}$ and Ca compared to $\mathrm{K}$ may have led to a relative higher leaching flux of $\mathrm{K}$.

The behavior of exchangeable $\mathrm{Ca}$ and $\mathrm{Al}$ in the beech and oak stands differed slightly form the other stands: the decrease in soil CEC in the topsoil layers seemed to impact more strongly exchangeable $\mathrm{Ca}$ and less strongly exchangeable Al pools (Fig. 9A). Despite the soil pH increase, Al remained very competitive with other basic cations under beech and oak in the topsoil layers. Since aluminum has a strong affinity for organic matter and remained abundant in these two stands, Al may have substituted $\mathrm{Ca}$ adsorbed on organic exchange sites, but the origin of this pattern which seems specific to the hardwood stands remains unclear.

\subsubsection{Pool size change in the organic layer between 2001- 2019}

The organic layer dry weight decreased between 2001 and 2019 for all stands except for the CwS and Nordmann fir stands (Supplementary material 5) most probably because of the successive thinnings. Indeed, between 1976 and 2001, the densely planted stands were not thinned. At the plantation, the density was 1600 tree.ha $^{-1}$ for coniferous and 15000 tree. ha $^{-1}$ for oak and beech.The opening of the canopy due to the thinnings carried out between 2001 and 2019 most likely increased the decomposition of the organic layer that had accumulated over the 1976-2001 period, as suggested by previous studies (Dahlgren and Driscoll, 1994; Legout et al., 2009; Vitousek et al., 1979). In the CwS stand, the increase in organic layer dry weight is in agreement with the accumulation of organic matter as the stand matures and may also be explained by the fact that no thinning or harvesting operations were carried between 1976 and 2019. In the Nordmann fir stand, the increase in organic layer dry weight may partly be due to an important production of fruit recorded in 2017. However, for both the CwS and Nordmann fir stands, an increase in carbon content in the topsoil layers was also recorded (Fig. 7) which suggests that the increase in organic layer dry weight is due to a slower organic matter decomposition. The strong increase in Ca stored in the organic layer of the Douglas fir stand can be explained by the biological cycle in this stand: the Ca concentration in the litterfall was higher in this stand compared to all others (data not shown). The mineral soil often represents the largest proportion of available nutrients in forest ecosystems and is often the only compartment taken into account in fertility budget studies. However, the organic layer cannot be neglected because it directly contributes to the replenishment of the plantavailable pools in the mineral soil and represents in many cases an important pool of nutrients (Jonard et al., 2009; Prescott et al., 2000).

\subsection{Tree species effect on soil chemical fertility}

While the tree species effect on soil chemical fertility and its change over time varied between the different tree species, similar behaviours were identified which led us to define three groups: i) Norway spruce and Nordmann fir, ii) Douglas fir and Laricio pine, and iii) Oak and Beech (Fig. 12). Several studies have focused on the effect of tree species on pedogenetic processes at the Breuil site (Legout et al., 2016; 
Mareschal, 2008....) and we discuss hereafter the consistency between these processes and our observations.

\subsubsection{Norway spruce, Nordmann fir}

Organic acids are released during the decomposition of organic matter contributes to the acidification of soils (Dijkstra et al., 2001). In the Nordmann fir stands, crypto podzolisation (i.e. acidolysis and chelation) seem predominant among the pedogenetic processes (Legout et al., 2016). Indeed, nitrate leaching is very limited in these stands and the vertical transfer of Al in the soil profile is mainly ensured by dissolved organic compounds, as suggested by the predominance of organically chelated Al species in the soil solutions (Legout et al., 2016; Mareschal, 2008). This is also the case under Norway spruce, but nitrate leaching is far from negligible (Legout et al., 2016), which reinforces the acidolysis process. Our results agree with this view and the important role of dissolved organic carbon and chelation processes in these stands. Indeed, the increase in soil carbon content between 2001 and 2019 suggests a slower and less complete decomposition of organic matter which is likely to release organic acids. $\mathrm{The}_{\mathrm{pH}} \mathrm{KCl}_{\text {average }}$ over the entire soil profile decreased for all two stands and this decrease is linked in the topsoil to the increase in carbon content (data not shown). The increase in carbon content also increased the number of negative charge balanced by $\mathrm{H}^{+}$and more protons could be exchanged with the solution, thus decreasing the soil $\mathrm{pH}$ value. Lower soil $\mathrm{pH}$ may have promote the dissolution of interfoliar Al hydroxides thus increasing the CEC in the topsoil; this increase may have partly compensated for the loss of nutrient cations. Acidolysis and chelation occurring in the topsoil layers in these stands did not result in the depletion of nutrient cations from the CEC over time and our hypothesis of moderate nutrient cation depletion for these stands was not verified.

\subsubsection{Laricio pine and Douglas fir}

In these stands, the excess of nitrate production (nitrification) over consumption is the cause of the higher acidity and the higher $\mathrm{Al}$ concentrations with a predominant $\mathrm{Al}^{3+}$ species in the soil solution as well as the higher leaching fluxes of $\mathrm{Mg}, \mathrm{Ca}$ and $\mathrm{K}$ compared to the other stands (Legout et al., 2016; Mareschal, 2008). In these stands, acidolysis is the main pedogenetic process (Legout et al., 2016). The C:N ratio decreased in the entire soil profile of the Douglas fir stand between 2001 and 2019 which concurs with elevated nitrification and elevated nitrate leaching. However, our initial hypothesis that nutrient depletion is more intense under these two stands is only partly validated. The depletion of exchangeable K pools was not greater than in the other stands. Soil pH decreased in the topsoil but not as strongly as in the Norway spruce and Nordmann fir stands (Fig. 12). What is more, the exchangeable pools of $\mathrm{Mg}$ and Ca increased in the Laricio pine and Douglas fir stands between 2001 and 2019 and the increase in exchangeable Ca pools in the Douglas fir stand was the greatest increase of all stands, probably in relation with biological cycling and the high Ca concentration in the litterfall under Douglas fir (data not shown). The strong on-going acidification evidenced by the monitoring of soil solutions (Legout et al., 2016) was not obvious for the solid phase of the soil when focusing on indicators such as soil pH, exchangeable acidity and exchangeable nutrient cation pools. This discrepancy between the solid and 
liquid phase may be caused by (i) higher mineral weathering in these stands (in relation to the acidity produced by nitrification), (ii) higher inputs of nutrient cations by atmospheric deposition and/or (iii) the CEC increase. In the Douglas fir stand, Legout et al., (2016) showed that atmospheric deposition of $\mathrm{Ca}$, $\mathrm{Mg}$ and $\mathrm{K}$ were higher compared to the other stands. In the Laricio pine stand, atmospheric deposition levels were similar to the other stands but it is likely that the $\mathrm{Ca}, \mathrm{Mg}$ and $\mathrm{K}$ losses in the leaching flux were compensated by the vertical transfer of $\mathrm{Ca}, \mathrm{Mg}$ and $\mathrm{K}$ from the organic layer to the mineral soil.

\subsubsection{Oak and beech}

The two broadleaved stands show signs of recovery from past acidification over the 2001-2019 period. The soil pH increased strongly (pvalue $<0.05$ ) in the $0-10 \mathrm{~cm}$ and over the entire soil profile but the CEC decreased over the entire soil profile as well as the nutrient cation pools.This significant behavior stands out from other coniferous species (Fig. 12). The decrease in soil CEC is most likely due to both the precipitation of Al hydroxides in the phyllosilicate interlayer space ( $\mathrm{pH}$ increase) and the better mineralization of the organic matter in these stands (the carbon content increase in the topsoil was the weakest for these two stands). For the same site, Trum et al., (2011) showed that organic matter decomposition was the fastest in the oak stand. The results support our initial hypothesis for the beech stand but the high demineralization in the oak stand hypothesis was not validated. According to Legout et al., (2016), the oak stand was the third stand with the highest excess of nitrate production but, contrarily to the Laricio pine and Douglas fir, the excess of nitrate production in the topsoil is compensated over the entire soil profile by nitrate consumption. This may contribute to explain why soil acidification in this stand was not intense despite the nitrification dynamics.

According to Mareschal (2008), the coniferous species at the Breuil-Chenue experimental site cause a higher acidification and a higher depletion of the exchangeable pools of nutrient cations in the following order: Norway spruce $\geq$ Laricio pine $=$ Douglas fir $>$ oak = beech. In a general way, our study agrees with this classification but the effect of acidolysis and chelation processes in Nordmann fir stand seems to be more damaging for the solid phase than previously, with a substantial decrease of $\mathrm{pH}$ and an increase of exchange acidity in the topsoil layers. Our study also confirm that tree species directly influence pedogenetic processes over short to mid-term time periods (up to 43 years) as suggested by previous studies .

\subsection{Ecosystem scale multi-criteria approach}

Used individually, static indicators such as soil pH, $\mathrm{CEC}$, pools of exchangeable cations may be misleading and their change over time does not necessarily reflect the processes occurring in the soil or the ecosystem. For instance, an increase in soil CEC over time is generally considered to be a sign of recovery from past soil acidification: an increase in soil $\mathrm{pH}$ often increases the number of active cationic exchange reaction sites (variable charge component of the CEC) (Camberato, 2001; Helling et al., 1964). In our study, we showed that the CEC increase under certain tree species (Douglas fir, Norway spruce, Nordmann fir, etc.) is associated with a decrease in soil $\mathrm{pH}$ and thus indicates a degradation of the soil for these species rather than a recovery. Yet, this CEC increase also resulted in an increase in 
exchangeable nutrient cations available for tree uptake and growth. This illustrates both (i) the necessity to study and compare different static soil indicators in order to assess the intensity of on-going soil processes and their consequences in terms of chemical fertility and (ii) the importance of assessing the consequences of these processes and changes over time on the other components and functions of the ecosystem.

The multi-criteria approach that is proposed here aims at better assessing the functioning of the ecosystem and how tree species influence its functioning as a whole. Such multi-criteria approaches (which may encompass broader criteria than those selected in this study) coupled with the knowledge of the processes and functioning of ecosystems enable to help rational forest management (Schwaiger et al., 2019).

For this purpose, tree species effects on soil chemical fertility were compared to other ecosystem functions reported in previous studies carried out at the Breuil-Chenue experimental site such as wood/biomass production, chemical quality of the draining water and soil fungal biodiversity (Fig. 10).

Depending on the criteria used the interpretation of the tree species effect on the functioning of the forest ecosystem can be very different. Our results underline the importance of taking into account the capacity of the soil to sustain over the long term the different ecosystem functions. This is best illustrated by the Douglas fir case (Fig. 10). Although the biomass production for this species is remarkable, other ecosystem functions are severely degraded (chemical quality of draining water and fungal diversity) and the 'cost' of this elevated production in terms of soil chemical fertility is very high. The very strong ongoing acidification may currently enable to maintain sufficient amounts of plant-available nutrients in the soil for tree growth but it is highly uncertain whether this tree growth rate may be sustained over the long term (more than a forest revolution). What is more, the strong modifications induced by this species in less than 50 years questions the capacity of the soil to supply available nutrients over the long term thus ensuring all ecosystem function necessary for the growth of future stands. Our results also raise concerns for the other coniferous stands although their tree species effect is often not as strong as the Douglas fir.

\section{Conclusion}

The increase in soil pH and in exchangeable $\mathrm{Mg}$ and $\mathrm{Ca}$ in most stands and soil layers between 2001 and 2019 may suggest that the soil at the Breuil-Chenue experimental site is recovering from past acidification. However, the decrease of $\mathrm{pH}$ and the increase of exchange acidity and cationic exchange capacity (CEC) in the topsoil layers under coniferous stands and the overall decrease of exchangeable $\mathrm{K}$ pools in most stands highlighted that soil acidification and/or crypto podzolisation are still on-going at this site. Tree species influence the pedogenetic processes occurring at the Breuil Chenue site, but our initial hypothesis that these processes would be accompanied by the depletion of exchangeable nutrient cation pools was not validated since Mg and Ca pools increased between 2001 and 2019. The changes in soil chemical properties over time were mainly explained by the changes in soil CEC which was 
probably due to the increase in carbon content in the topsoil and/or to the dynamics of precipitation/dissolution of $\mathrm{Al}$ (hydr)oxides in the interfoliar space of phyllosilicates. The increase in soil CEC over time may have partly compensated for the loss of nutrient cations, especially in the coniferous stands. Our results illustrate how important the choice of the adequate indicators is to characterize and quantify the changes in soil fertility over time because different indicators may lead to opposed conclusions.

Our study demonstrate that tree species strongly influence how nutrient pools in the soil change over time. Our hypotheses which were that the chemical degradation of fertility would be (i) high in Douglas fir and laricio pine, due mainly to acidolysis linked to the high rate of nitrification and leaching of nutrient cations, (ii) intermediate in the Nordman fir, Norway spruce and oak due to acidolysis and chelation (in connection with the release of organic acids from the transformation of organic matter) and (iii) less intense in the plot beech are not completely verified.

Based on their behavior, we were able to distinguish three groups of species: i) Nordmann fir and Norway spruce with acidolysis and chelation processes (related to the release of organic acids from organic matter transformation), resulting in the most intense changes in topsoil properties (e.g. decrease in $\mathrm{pH}$, increase in exchange acidity), ii) Douglas fir and Laricio pine, where the strong acidification occurring (related to high nitrification rate and nutrient cation leaching) is probably compensated by a greater weathering and/or atmospheric depositions fluxes, and iii) Oak and beech with a lower soil acidification compared to all the other stands. However, even if signs of soil acidification recovery occurred in these deciduous stands between 2001 and 2019, the decrease in soil CEC did not allow to improve significantly the exchangeable nutrient pools over the soil profile.

Finally, our study highlights the difficulties of comparing multiple indicators and shows just how necessary multi-criteria approaches are to properly understand how the ecosystem functions. Tree species selection by the forest manager should be based on such multi-criteria approaches to properly account for the different ecosystem functions and services, opportunities and threats.

\section{Abbreviations}
Al: Aluminium
Ca: Calcium
C: Carbon

C:N: Carbon to nitrogen ratio

CEC : Cationic exchange capacity

CwS : Coppice with standards 
EA: Exchange acidity $(\mathrm{H}+\mathrm{Al})$

H: Hydrogen

K: Potassium

Mg: Magnesium

N: Nitrogen

$\mathrm{NO}_{3}{ }^{-}$: Nitrates

ONF: French National Forest Office

S: Sum of basic cations $(\mathrm{Ca}+\mathrm{Mg}+\mathrm{K})$

\section{Declarations}

\section{Aknowledgements}

This site belongs to French national research infrastructure ANAEE-France (ANR-11-INBS-0001). We gratefully acknowledge the financial support received successively from GIP ECOFOR, AllEnvi, ANAEE France, the LTSER Zone Atelier Bassin Moselle and INRAE (DISC, ECODIV).

We are also grateful the Parc Naturel Régional du Morvan. We thank INRAE and Office National des Forêts for financing Margaux Clesse-s doctoral thesis.

We would also like to thank l'Office National des Forêts, Dominique Gelhaye, Pascal Bonnaud, Serge Didier, Benoît Pollier and Gilles Nourrisson for their contribution to the Breuil-Chenue site management, sampling and analysis over the years.

The UR-1138 INRAE - Biogeochimie des Ecosystemes Forestiers is supported by a grant overseen by the French National Research Agency (ANR) as part of the "Investissement d'Avenir" program (ANR-11-LABX0002-01, Lab of Excellence ARBRE).

\section{Authors' contributions}

MC conceptualized, investigated, analyzed, wrote the original draft, reviewed and edited the study. AL conceptualized, investigated, analyzed, reviewed, edited, supervised the study and acquired funds. BZ reviewed, edited and supervised the study. JR provided the data resources, reviewed and edited the study. GvdH conceptualized, investigated, analyzed, reviewed, edited, supervised the study and acquired funds.

\section{Funding}


The study was funded successively by GIP ECOFOR, AllEnvi, ANAEE France, the LTSER Zone Atelier Bassin Moselle and INRAE (DISC, ECODIV).

\section{Availability of data and materials}

The datasets used and/or analysed during the current study are available from the corresponding author on reasonable request.

\section{Ethics approval and consent to participate}

Not applicable.

\section{Consent for publication}

Not applicable.

\section{Competing of interest}

The authors declare that they have no competing interests.

\section{References}

1. Achat DL, Deleuze C, Landmann G, Pousse N, Ranger J, Augusto L (2015) Quantifying consequences of removing harvesting residues on forest soils and tree growth - A meta-analysis. Forest Ecology and Management 348, 124-141. https://doi.org/10/f7fcbh

2. Andrianarisoa KS, Zeller B, Poly F, Siegenfuhr H, Bienaimé S, Ranger J, Dambrine E (2010) Control of Nitrification by Tree Species in a Common-Garden Experiment. Ecosystems 13, 1171-1187. https://doi.org/10/fcc47n

3. Anne P (1945) Sur le dosage rapide du carbone organique des sols.Annales Agronomiques161-172

4. Augusto L, Bonnaud P, Ranger J (1998) Impact of tree species on forest soil acidification. For Ecol Manag 105:67-78. https://doi.org/10.1016/S0378-1127(97)00270-3

5. Augusto L, De Schrijver A, Vesterdal L, Smolander A, Prescott C, Ranger J (2015) Influences of evergreen gymnosperm and deciduous angiosperm tree species on the functioning of temperate and boreal forests: Spermatophytes and forest functioning. Biol Rev 90, 444-466. https://doi.org/10/f68486

6. Augusto L, Ranger J, Binkley D, Rothe A (2002) Impact of several common tree species of European temperate forests on soil fertility. Ann For Sci 59:233-253. https://doi.org/10.1051/forest:2002020

7. Augusto L, Ranger J, Bonneau M (2000) Influence des essences sur la fertilité chimique des sols Conséquences sur les choix sylvicoles. Revue Forestière Française LII 507-518. https://doi.org/10.4267/2042/5384

8. Bergkvist B, Folkenson L (1995) The influence of tree species on acid deposition, proton budgets and element fluxes in south Swedish forest ecosystems. Ecological Bulletins 44:90-99 
9. Binkley D (1995) The influence of tree species on forest soils: processes and patterns (Mead D.J., Cornforth I.S. (Eds.), Proceedings of the Tree and soil Workshop, Agronomy Society of New Zealand, Canterbury)

10. Bolte A, Ammer C, Löf M, Nabuurs G-J, Schall P, Spathelf P (2009) Adaptive Forest Management: A Prerequisite for Sustainable Forestry in the Face of Climate Change. In: Spathelf P (ed) Sustainable Forest Management in a Changing World: A European Perspective. Springer Netherlands, Dordrecht, pp 115-139. https://doi.org/10.1007/978-90-481-3301-7_8

11. Bouvet A, Deroubaix G, Lanvin JD, Levet AL, Savagner L, Thivolle-Cazat A, Weiller G (2019)MementoFCBA

12. Boxman AW, Peters RCJH, Roelofs JGM (2008) Long term changes in atmospheric $\mathrm{N}$ and $\mathrm{S}$ throughfall deposition and effects on soil solution chemistry in a Scots pine forest in the Netherlands. Environmental Pollution 156, 1252-1259. https://doi.org/10/brdw8f

13. Brêthes A, Brun J, Jabiol B, Ponge J, Toutain F (1995) Classification of forest humus forms: a French proposal. Ann. For. Sci. 52, 535-546. https://doi.org/10/crkx3k

14. Brown AHF, Iles MA (1991) Water Chemistry Profiles under Four Tree Species at Gisburn, NW England. Forestry 64, 169-187. https://doi.org/10/cn47vn

15. Buée M, Maurice J-P, Zeller B, Andrianarisoa S, Ranger J, Courtecuisse R, Marçais B, Le Tacon F (2011) Influence of tree species on richness and diversity of epigeous fungal communities in a French temperate forest stand. Fungal Ecology 4, 22-31. https://doi.org/10/bvd2qk

16. Camberato J (2001) Cation exchange capacity everything you want to know and much more. S.C. Turfgrass Found. News Oct-Dec 2001

17. Carnol M, Bazgir M (2013) Nutrient return to the forest floor through litter and throughfall under 7 forest species after conversion from Norway spruce. Forest Ecology and Management 309, 66-75. https://doi.org/10/f5mdg6

18. Ciesielski H, Sterckeman T, Santerne M, Willery JP (1997a) Determination of cation exchange capacity and exchangeable cations in soils by means of cobalt hexamine trichloride. Effects of experimental conditions. Agronomie 17, 1-7. https://doi.org/10/d3vh29

19. Ciesielski H, Sterckeman T, Santerne M, Willery JP (1997b) A comparison between three methods for the determination of cation exchange capacity and exchangeable cations in soils. Agronomie 17, 916. https://doi.org/10/fpc354

20. Cremer M, Prietzel J (2017) Soil acidity and exchangeable base cation stocks under pure and mixed stands of European beech, Douglas fir and Norway spruce. Plant Soil 415, 393-405. https://doi.org/10/gbjzhz

21. Dahlgren RA, Driscoll CT (1994) The effects of whole-tree clear-cutting on soil processes at the Hubbard Brook Experimental Forest, New Hampshire, USA. Plant Soil 158, 239-262. https://doi.org/10/cqczvm

22. Davies GM, Gray A (2015) Don't let spurious accusations of pseudoreplication limit our ability to learn from natural experiments (and other messy kinds of ecological monitoring). Ecol Evol 5, 5295- 
5304. https://doi.org/10/f724v6

23. De Schrijver A, Geudens G, Augusto L, Staelens J, Mertens J, Wuyts K, Gielis L, Verheyen K (2007) The effect of forest type on throughfall deposition and seepage flux: a review.Oecologia663-674

24. De Turckheim B (1990) L'intensité en sylviculture. Quelques réflexions sur l'orientation de la gestion dans nos forêts. Revue Forestière Française XLII, 475-494. https://doi.org/10/ctp28c

25. DeSutter TM, Pierzynski GM, Baker LR (2006) Flow-Through and Batch Methods for Determining Calcium-Magnesium and agnesium-Calcium Selectivity. Soil Sci Soc Am J 550-554. https://doi.org/10.2136/sssaj2005.0065N

26. Dijkstra FA, Geibe C, Holmström S, Lundström US, Van Breemen N (2001) The effect of organic acids on base cation leaching from the forest floor under six North American tree species: Organic acidity in forest soils. European Journal of Soil Science 52, 205-214. https://doi.org/10/bhjh88

27. Duchaufour $P$ (1970) Précis de pédologie, 3ème édition. ed. Masson \& Cie, Paris

28. Engardt M, Simpson D, Schwikowski M, Granat L (2017) Deposition of sulphur and nitrogen in Europe 1900-2050. Model calculations and comparison to historical observations. Tellus B: Chemical and Physical Meteorology 69, 1-20. https://doi.org/10/gbn4vc

29. Espiau P, Peyronel A (1976) L'acidité d'échange des sols, le taux d'acidité d'échange et sa signification pédologique sous climat tempéré. Annales Agronomiques 31:363-383

30. Gruba P, Mulder J (2015) Tree species affect cation exchange capacity (CEC) and cation binding properties of organic matter in acid forest soils. Science of The Total Environment 511, 655-662. https://doi.org/10/f65cch

31. Hansson K, Laclau J-P, Saint-André L, Mareschal L, van der Heijden G, Nys C, Nicolas M, Ranger J, Legout A (2020) Chemical fertility of forest ecosystems. Part 1: Common soil chemical analyses were poor predictors of stand productivity across a wide range of acidic forest soils. Forest Ecology and Management 461, 117843. https://doi.org/10/ggnzjm

32. Helling CS, Chesters G, Corey RB (1964) Contribution of Organic Matter and Clay to Soil CationExchange Capacity as Affected by the $\mathrm{pH}$ of the Saturating Solution. Soil Science Society of America Journal 28, 517-520. https://doi.org/10/bdn2fh

33. Hurlbert SH (2004) On misinterpretations of pseudoreplication and related matters: a reply to Oksanen. Oikos 104, 591-597. https://doi.org/10/ckw5x5

34. Jonard M, Augusto L, Morel C, Achat DL, Saur E (2009) Forest floor contribution to phosphorus nutrition: experimental data. Ann. For. Sci. 66, 510-510. https://doi.org/10/dcznf8

35. Kaplan JO, Krumhardt KM, Zimmermann N (2009) The prehistoric and preindustrial deforestation of Europe. Quaternary Science Reviews 28, 3016-3034. https://doi.org/10/ckj3pn

36. Legout A, Hansson K, van der Heijden G, Laclau J-P, Mareschal L, Nys C, Nicolas M, Saint-André L, Ranger J (2020) Chemical fertility of forest ecosystems. Part 2: Towards redefining the concept by untangling the role of the different components of biogeochemical cycling. Forest Ecology and Management 461, 117844. https://doi.org/10/ggnzc9 
37. Legout A, Nys C, Picard J-F, Turpault M-P, Dambrine E (2009) Effects of storm Lothar (1999) on the chemical composition of soil solutions and on herbaceous cover, humus and soils (Fougères, France). Forest Ecology and Management 257, 800-811. https://doi.org/10/ctm5z7

38. Legout A, Van der Heijden G, Jaffrain J, Boudot J-P, Ranger J (2016) Tree species effects on solution chemistry and major element fluxes: A case study in the Morvan (Breuil, France). For Ecol Manag 378:244-258. https://doi.org/10.1016/j.foreco.2016.07.003

39. Mareschal L (2008) Effet des substitutions d'essences forestières sur l'évolution des sols et de leur minéralogie: bilan après 28 ans dans le site expérimental de Breuil (Morvan). Université Henri Poincaré - Nancy 1.

40. Mareschal L, Bonnaud P, Turpault MP, Ranger J (2010) Impact of common European tree species on the chemical and physicochemical properties of fine earth: an unusual pattern. European Journal of Soil Science 61, 14-23. https://doi.org/10/dpnjp6

41. Mareschal L, Ranger J, Turpault MP (2009) Stoichiometry of a dissolution reaction of a trioctahedral vermiculite at $\mathrm{pH}$ 2.7. Geochimica et Cosmochimica Acta 13. https://doi.org/10/d5xxcb

42. Mareschal L, Turpault M-P, Bonnaud P, Ranger J (2013) Relationship between the weathering of clay minerals and the nitrification rate: a rapid tree species effect. Biogeochemistry 112, 293-309. https://doi.org/10/f4qs2x

43. Moukoumi J, Munier-Lamy C, Berthelin J, Ranger J (2006) Effect of tree species substitution on organic matter biodegradability and mineral nutrient availability in a temperate topsoil. Ann For Sci 63:763-771. https://doi.org/10.1051/forest:2006057

44. Paré D, Thiffault E (2016) Nutrient Budgets in Forests Under Increased Biomass Harvesting Scenarios. Current Forestry Reports 2, 81-91. https://doi.org/10/ggx8c2

45. Poonia SR, Niederbudde EA (1990) Exchange equilibria of potassium in soils, V. Effect of natural organic matter on K-Ca exchange. Geoderma 47:233-242

46. Prechtel A, Alewell C, Armbruster M, Bittersohl J, Cullen J, Evans C, Helliwell R, Kopácek J, Marchetto A, Matzner E, Meesenburg H, Moldan F, Moritz K, Veselý J, Wright R (2001) Response of sulphur dynamics in European catchments to decreasing sulphate deposition. Hydrol Earth Syst Sci 5:311325. https://doi.org/10.5194/hess-5-311-2001

47. Prescott CE, Maynard DG, Laiho R (2000) Humus in northern forests: friend or foe? Forest Ecology and Management 133, 23-36. https://doi.org/10/dn3rdm

48. Puech J (2009) Mise en valeur de la forêt française et développement de la filière bois. Paris

49. Ranger J (1995) Le cycle biogéochimique des éléments majeurs dans les écosystèmes forestiers. Étude et Gestion des Sols 2:119-134

50. Ranger J, Andreux F, Bienaimé S, Berthelin J, Bonnaud P, Boudot JP, Bréchet C, Buée M, Calmet J, Chaussod R, Gelhaye D, Gelhaye L, Gérard F, Jaffrain J, Lejon D, Le Tacon F, Lévêque J, Maurice J, Merlet D, Moukoumi J, Munier-Lamy C, Nourrisson G, Pollier B, Ranjard L, Simonsson M, Turpault MP, Vairelles D, Zeller B (2004) Effet des substitutions d'essence sur le fonctionnement organo-minéral de l'écosystème forestier, sur les communautés microbiennes et sur la diversité des communautés 
fongiques mycorhiziennes et saprophytes (cas du dispositif de Breuil - Morvan), Rapport final contrat INRA-GIP Ecofor 2001-24, No. INRA 1502A. INRA Biogéochimie des Ecosystèmes Forestiers (UR 1138), 54280 Champenoux.

51. Ranger J, Gerard F, Lindemann M, Gelhaye D, Gelhaye L (2002) Dynamics of litterfall in a chronosequence of Douglas-fir (Pseudotsuga menziesii Franco) stands in the Beaujolais mounts (France). Ann For Sci 60:475-488. https://doi.org/10.1051/forest:2003041

52. Rothe A, Huber C, Kreutzer K, Weis W (2002) Deposition and soil leaching in stands of Norway spruce and European Beech: Results from the Höglwald research in comparison with other European case studies.Plant and Soil33-45

53. Rouiller J, Guillet B, Bruckert S (1980) Cations acides échangeables et acidité de surface. Approche analytique et incidence pédogénétiques. Bulletin de l'association Française d'Etude des Sols 2:171175

54. Rovira P, Vallejo VR (2002) Labile and recalcitrant pools of carbon and nitrogen in organic matter decomposing at different depths in soil: an acid hydrolysis approach. Geoderma 109-141. https://doi.org/10/fh4fhc

55. Schwaiger F, Poschenrieder W, Biber P, Pretzsch H (2019) Ecosystem service trade-offs for adaptive forest management. Ecosystem Services 39, 100993. https://doi.org/10/ghmrn3

56. Tamura T (1958) Identification of clay minerals from acid soils. J Soil Sci 9:141-147

57. Thurm EA, Hernandez L, Baltensweiler A, Ayan S, Rasztovits E, Bielak K, Zlatanov TM, Hladnik D, Balic B, Freudenschuss A, Büchsenmeister R, Falk W (2018) Alternative tree species under climate warming in managed European forests. Forest Ecology and Management 430, 485-497. https://doi.org/10/gfnc6n

58. Trum F, Titeux H, Ranger J, Delvaux B (2011) Influence of tree species on carbon and nitrogen transformation patterns in forest floor profiles. Ann For Sci 68:837-847. https://doi.org/10.1007/s13595-011-0080-4

59. van der Heijden G, Legout A, Pollier B, Mareschal L, Turpault M-P, Ranger J, Dambrine E (2013) Assessing $\mathrm{Mg}$ and $\mathrm{Ca}$ depletion from broadleaf forest soils and potential causes - A case study in the Morvan Mountains. Forest Ecology and Management 293, 65-78. https://doi.org/10/ghnnd3

60. van der Heijden G, Legout A, Pollier B, Ranger J, Dambrine E (2014) The dynamics of calcium and magnesium inputs by throughfall in a forest ecosystem on base poor soil are very slow and conservative: evidence from an isotopic tracing experiment (26Mg and $44 \mathrm{Ca})$. Biogeochemistry 118 , 413-442. https://doi.org/10/f5wcbw

61. Verstraeten A, Neirynck J, Genouw G, Cools N, Roskams P, Hens M (2012) Impact of declining atmospheric deposition on forest soil solution chemistry in Flanders, Belgium. Atmospheric Environment 62, 50-63. https://doi.org/10/f4gn2q

62. Vesterdal L, Schmidt IK, Callesen I, Nilsson LO, Gundersen P (2008) Carbon and nitrogen in forest floor and mineral soil under six common European tree species. For Ecol Manag 255:35-48. https://doi.org/10.1016/j.foreco.2007.08.015 
63. Vitousek PM, Gosz JR, Grier CC, Melillo JM, Reiners WA, Todd RL (1979) Nitrate Losses from Disturbed Ecosystems. Science 204, 469-474. https://doi.org/10/d9bwtc

64. Vuorenmaa J, Augustaitis A, Beudert B, Clarke N, de Wit HA, Dirnböck T, Frey J, Forsius M, Indriksone I, Kleemola S, Kobler J, Krám P, Lindroos A-J, Lundin L, Ruoho-Airola T, Ukonmaanaho L, Váňa M (2017) Long-term sulphate and inorganic nitrogen mass balance budgets in European ICP Integrated Monitoring catchments (1990-2012). Ecological Indicators 76, 15-29. https://doi.org/10/gbr28d

65. Zeller B, Legout A, Bienaimé S, Gratia B, Santenoise P, Bonnaud P, Ranger J (2019) Douglas fir stimulates nitrification in French forest soils. Sci Rep 9, 10687. https://doi.org/10/ghnndv

66. Zeller B, Recous S, Kunze M, Moukoumi J, Colin-Belgrand M, Bienaimé S, Ranger J, Dambrine E (2007) Influence of tree species on gross and net $\mathrm{N}$ transformations in forest soils. Ann For Sci 64:151-158. https://doi.org/10.1051/forest:2006099

\section{Table}

Tab.1: Statistical significance (95\% confidence) of differences between tree species in 2001 and 2019 (letters) and between the two sampling dates (asterisks; *: p-value <0.1, $\star *$ : $\mathrm{p}$-value $<0.05$ ) for $\mathrm{Ca}, \mathrm{Mg}$ and $\mathrm{K}$ stocks in the soil (exchangeable pool) and organic layer. 


\begin{tabular}{|c|c|c|c|c|c|c|c|c|c|c|}
\hline & & \multicolumn{3}{|l|}{$\mathrm{Ca}$} & \multicolumn{3}{|l|}{$\mathrm{Mg}$} & \multicolumn{3}{|l|}{$\mathrm{K}$} \\
\hline & & \multicolumn{2}{|c|}{$\begin{array}{l}\text { Species } \\
\text { effect }\end{array}$} & \multirow[t]{2}{*}{$\begin{array}{l}\text { Time } \\
\text { effect }\end{array}$} & \multicolumn{2}{|c|}{$\begin{array}{l}\text { Species } \\
\text { effect }\end{array}$} & \multirow[t]{2}{*}{$\begin{array}{l}\text { Time } \\
\text { effect }\end{array}$} & \multicolumn{2}{|c|}{$\begin{array}{l}\text { Species } \\
\text { effect }\end{array}$} & \multirow[t]{2}{*}{$\begin{array}{l}\text { Time } \\
\text { effect }\end{array}$} \\
\hline & & 2001 & 2019 & & 2001 & 2019 & & 2001 & 2019 & \\
\hline \multirow{7}{*}{$\begin{array}{l}\text { Organic } \\
\text { layer }\end{array}$} & CwS & $a$ & $b c$ & $\star \star$ & $a b$ & $a b$ & * & $a b$ & $b$ & \\
\hline & Beech & $a$ & $\mathrm{~cd}$ & & $b$ & $\mathrm{~cd}$ & * & $b$ & cde & $\star \star$ \\
\hline & Oak & $a$ & $c d$ & & $a b$ & $\mathrm{~cd}$ & & $a b$ & de & $\star \star$ \\
\hline & $\begin{array}{l}\text { Douglas } \\
\text { fir }\end{array}$ & $a$ & $a$ & $\star \star$ & $a$ & $a b$ & & $a b$ & bcd & \\
\hline & $\begin{array}{l}\text { Nordmann } \\
\text { fir }\end{array}$ & $a$ & $a b$ & $\star \star$ & $a b$ & $a b$ & $\star \star$ & $a b$ & $a$ & \\
\hline & $\begin{array}{l}\text { Laricio } \\
\text { pine }\end{array}$ & $a$ & $a b$ & & $a b$ & $d$ & & $a b$ & e & $\star \star$ \\
\hline & $\begin{array}{l}\text { Norway } \\
\text { spruce }\end{array}$ & $a$ & $\mathrm{bc}$ & & $a$ & $\mathrm{bc}$ & & $a$ & bcd & $\star \star$ \\
\hline \multirow[t]{7}{*}{ Soil } & CwS & $a b$ & $b$ & $\star \star$ & $a b$ & $a$ & * & bcd & $a$ & \\
\hline & Beech & $a$ & $\mathrm{~b}$ & & $a b c$ & $b$ & $\star \star$ & $\mathrm{cd}$ & $a$ & $\star \star$ \\
\hline & Oak & $a$ & $b$ & & $a b c$ & $a b$ & $\star \star$ & $a$ & $a$ & $\star \star$ \\
\hline & $\begin{array}{l}\text { Douglas } \\
\text { fir }\end{array}$ & $a$ & $a$ & $\star \star$ & $a$ & $a b$ & & $\mathrm{bc}$ & $a$ & $\star \star$ \\
\hline & $\begin{array}{l}\text { Nordmann } \\
\text { fir }\end{array}$ & $\mathrm{b}$ & $b$ & $\star \star$ & $C$ & $b$ & ** & $d$ & $a$ & \\
\hline & $\begin{array}{l}\text { Laricio } \\
\text { pine }\end{array}$ & $a b$ & $b$ & & $\mathrm{bc}$ & $b$ & & $\mathrm{~cd}$ & $a$ & $\star \star$ \\
\hline & $\begin{array}{l}\text { Norway } \\
\text { spruce }\end{array}$ & $a b$ & $b$ & & $a b c$ & $b$ & & $\mathrm{~b}$ & $a$ & $\star \star$ \\
\hline
\end{tabular}

Figures 
Sampling of studied plots in 2001 and 2019

Bloc 1

A."



Forest road

\section{Figure 1}

Diagram of the Breuil-Chenue experimental site adapted from van der Heijden et al.,(2013a). Location of the various plots and sampling points in 1974, 2001 and 2019. 


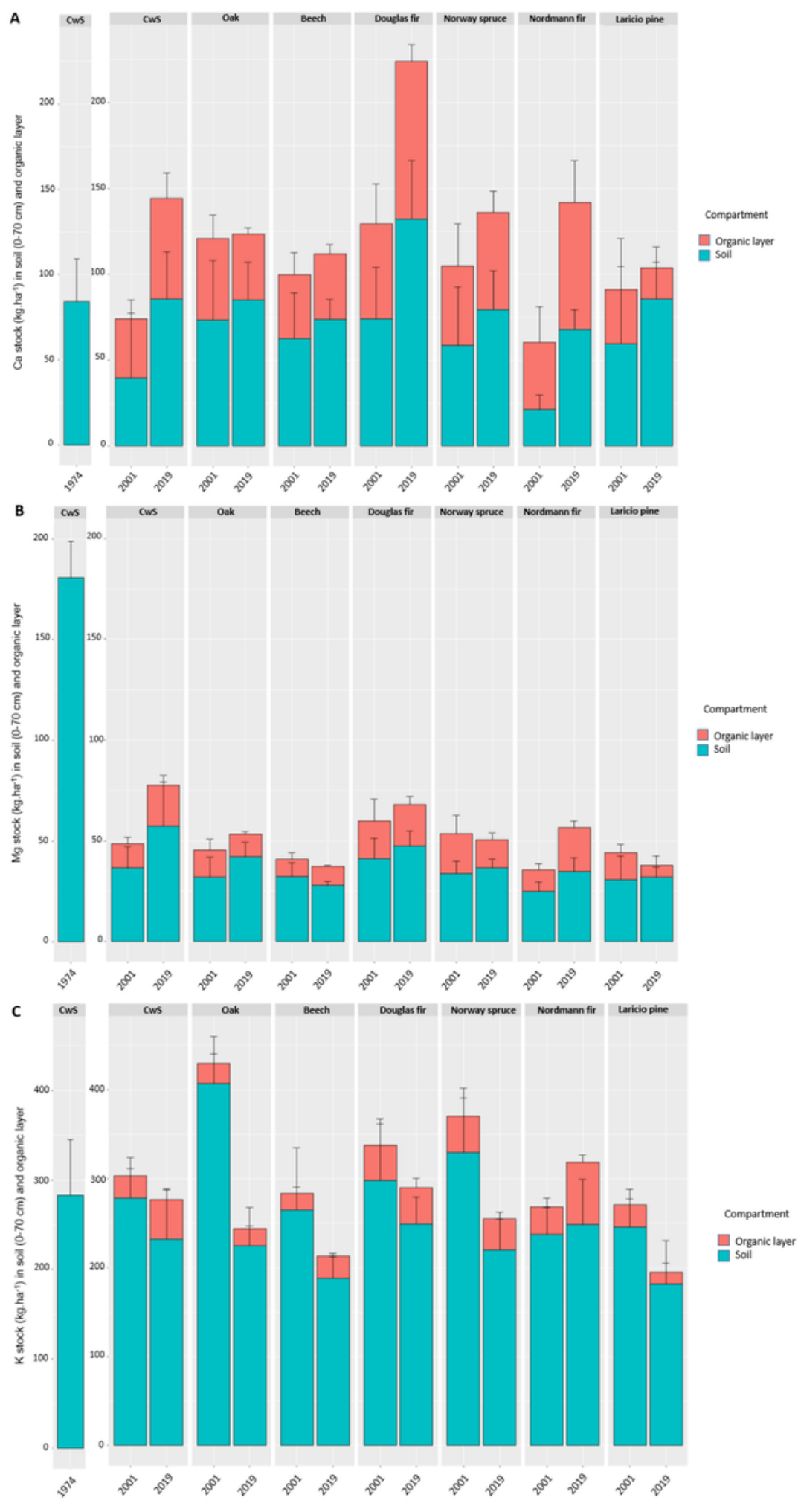

Figure 2

Pools of calcium (A), magnesium (B) and potassium (C) in the organic layer and the 0-70 $\mathrm{cm}$ mineral soil (exchangeable pools) in 1974, 2001 and 2019 in the different monospecific plots of the Breuil-Chenue site. The 1974 soil samples were collected in the native coppice with standards forest prior to the site installation. 


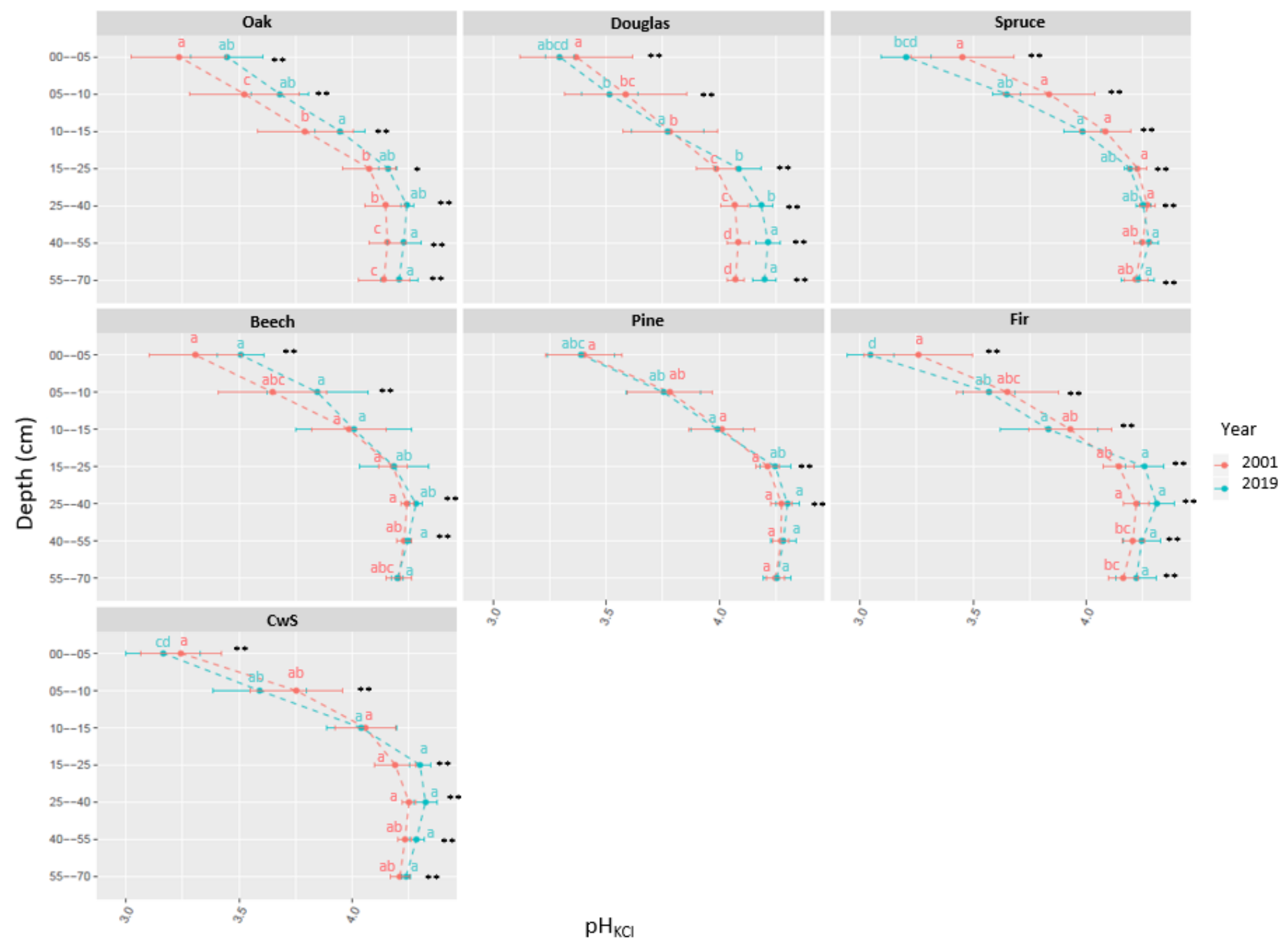

Figure 3

Soil pH KCl for the different tree species and sampled soil layers between 2001 and 2019. Different letters indicate statistical significant (95\% confidence) differences between tree species in 2001 and 2019 and asterisk indicate differences between 2001 and 2019 (*: p-value <0.1; **: p-value <0.05). 


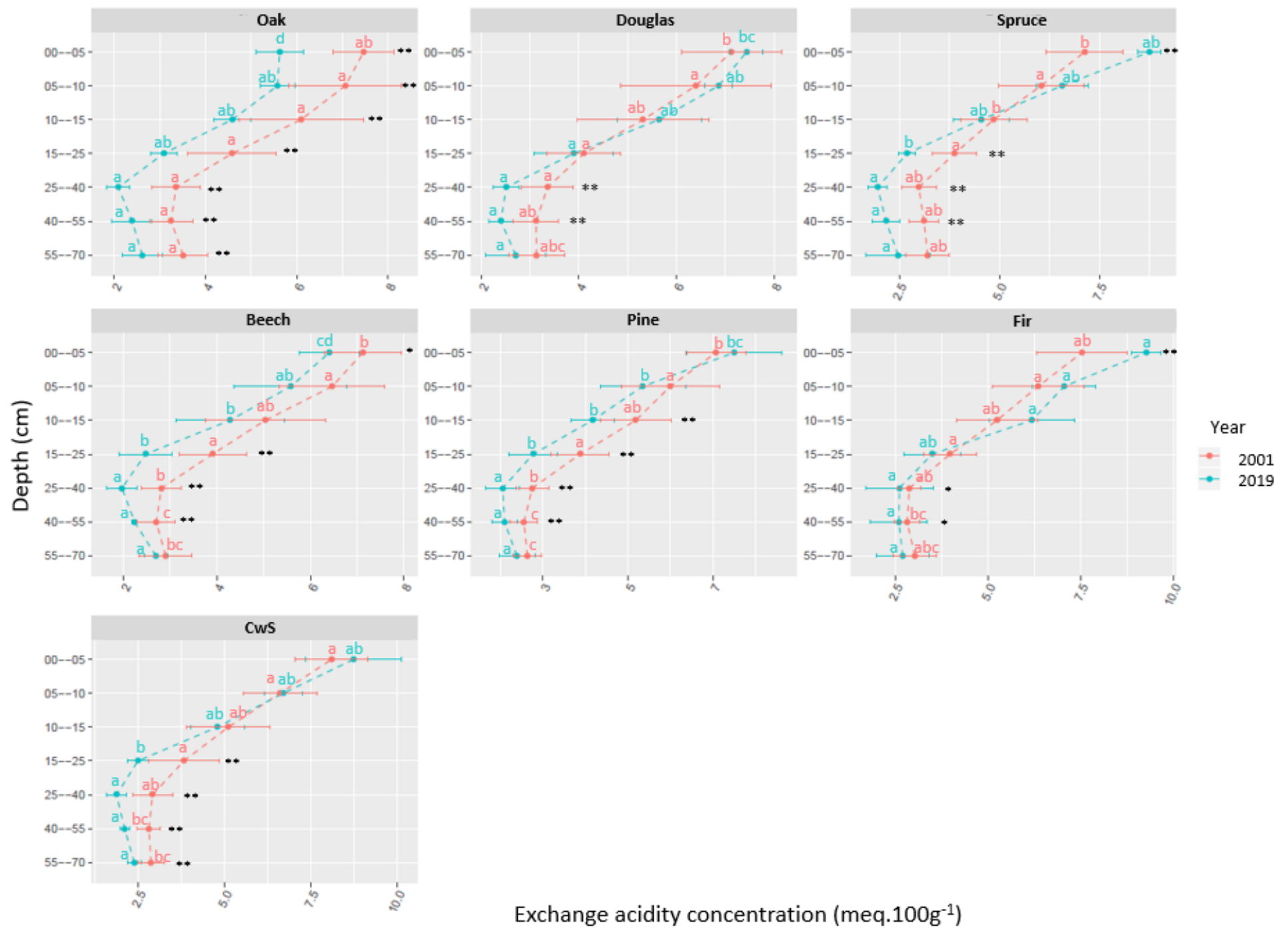

\section{Figure 4}

Exchange acidity of soil (EA) for the different tree species and sampled soil layers between 2001 and 2019. Different letters indicate statistical significant ( $95 \%$ confidence) differences between tree species in 2001 and 2019 and asterisk indicate differences between 2001 and 2019 (*: p-value <0.1; **: p-value $<0.05)$. 


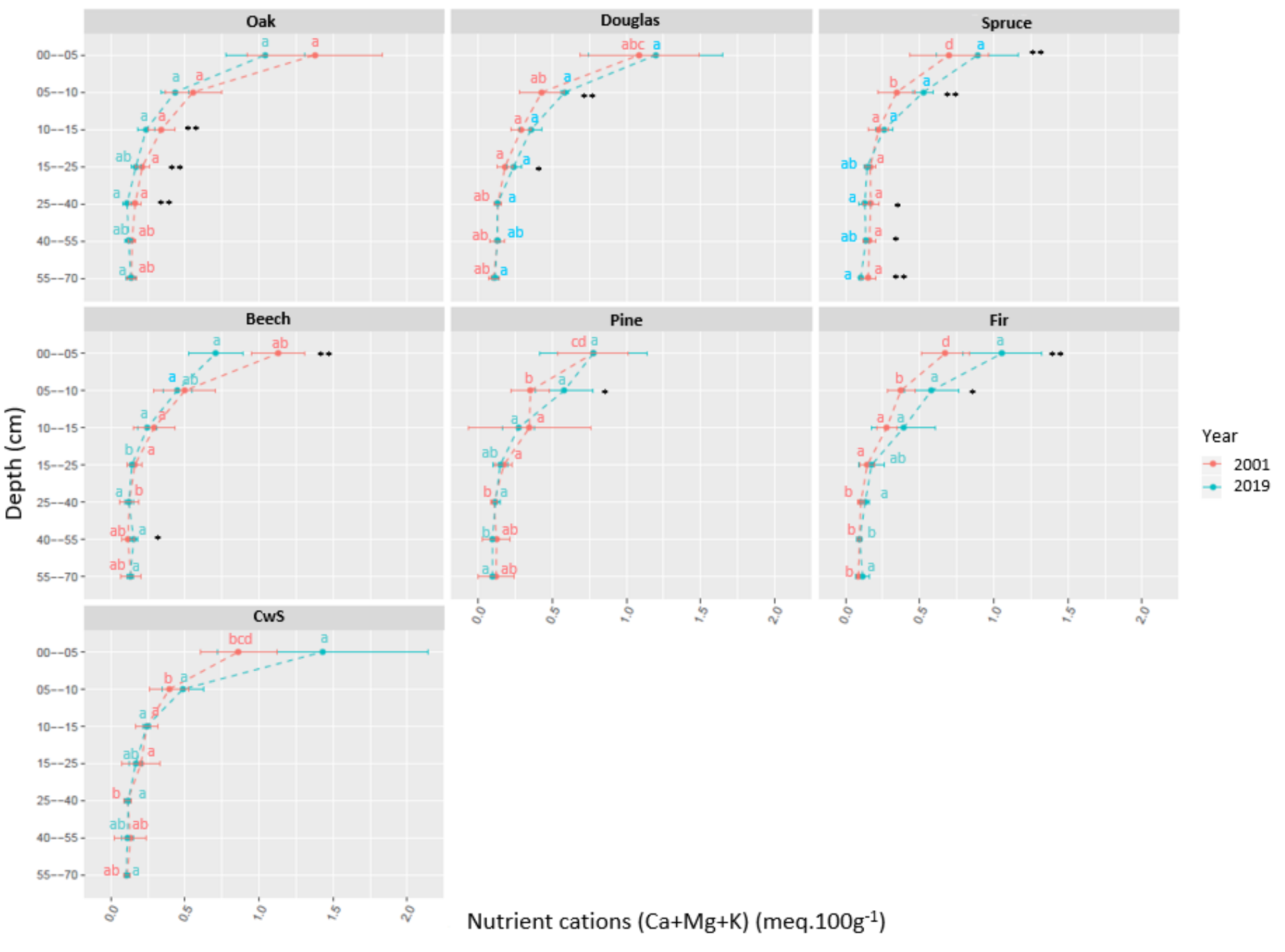

Figure 5

Sum of nutrient cations in soil (S) for the different tree species and sampled soil layers between 2001 and 2019. Different letters indicate statistical significant (95\% confidence) differences between tree species in 2001 and 2019 and asterisk indicate differences between 2001 and 2019 (*: p-value <0.1; **: pvalue $<0.05)$. 


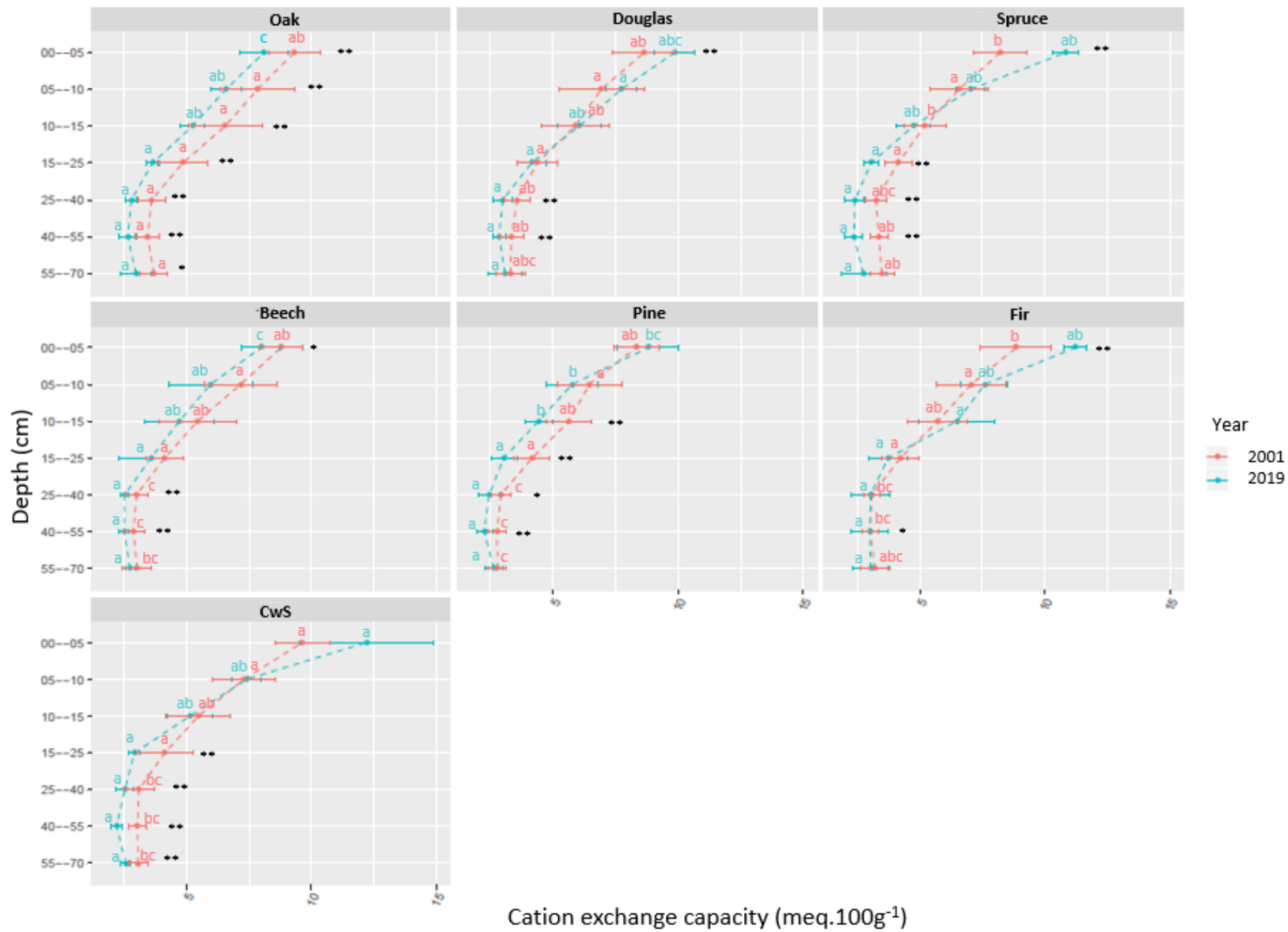

Figure 6

Soil CEC for the different tree species and sampled soil layers between 2001 and 2019. Different letters indicate statistical significant (95\% confidence) differences between tree species in 2001 and 2019 and asterisk indicate differences between 2001 and 2019 (*: p-value <0.1; **: p-value <0.05). 


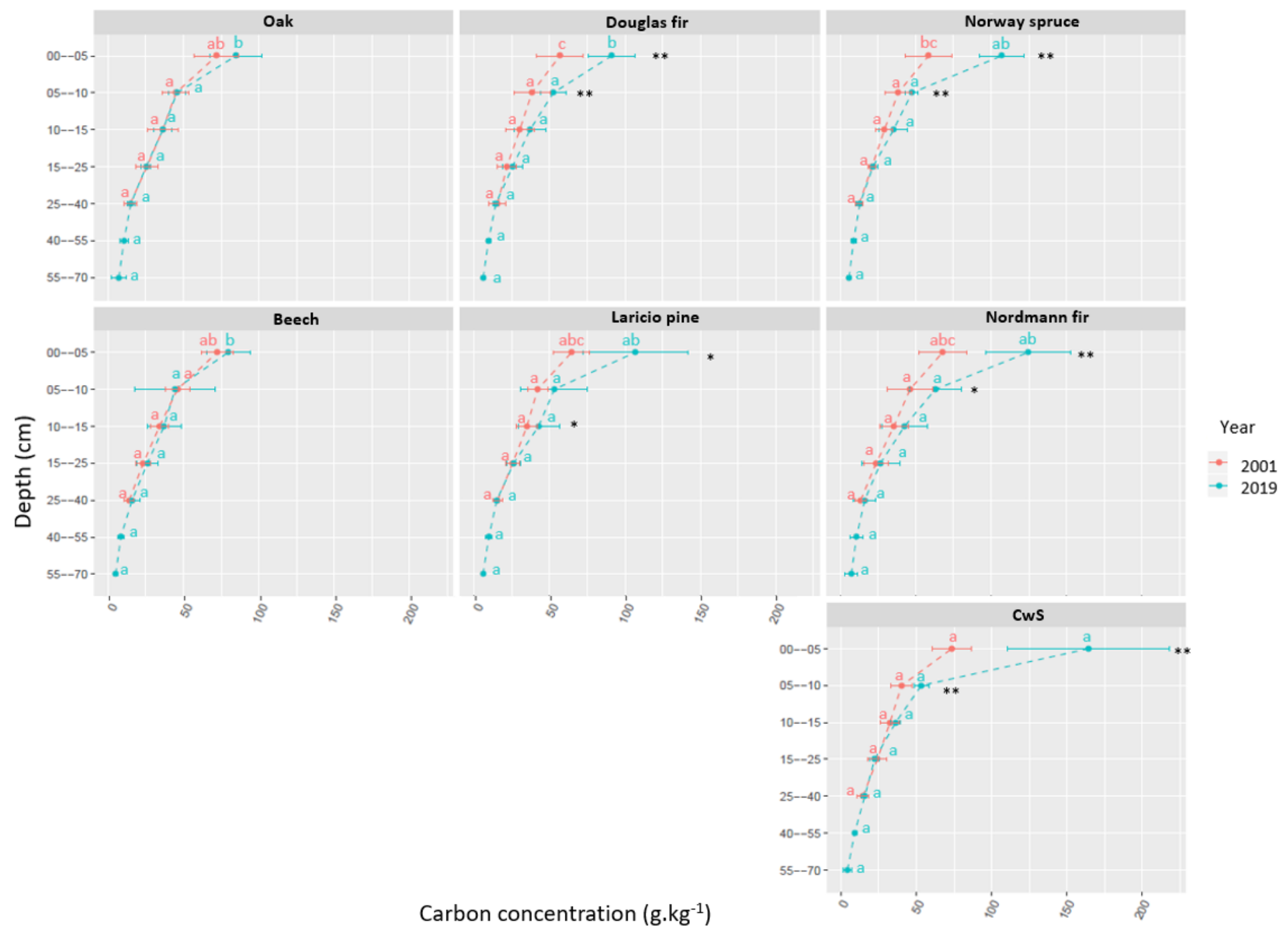

Figure 7

Soil carbon content ( $\mathrm{g} \mathrm{kg}-1)$ for the different tree species and sampled soil layers between 2001 and 2019. Different letters indicate statistical significant (95\% confidence) differences between tree species in 2001 and 2019 and asterisk indicate differences between 2001 and 2019 (*: p-value <0.1; $* *$ : p-value $<0.05)$. 

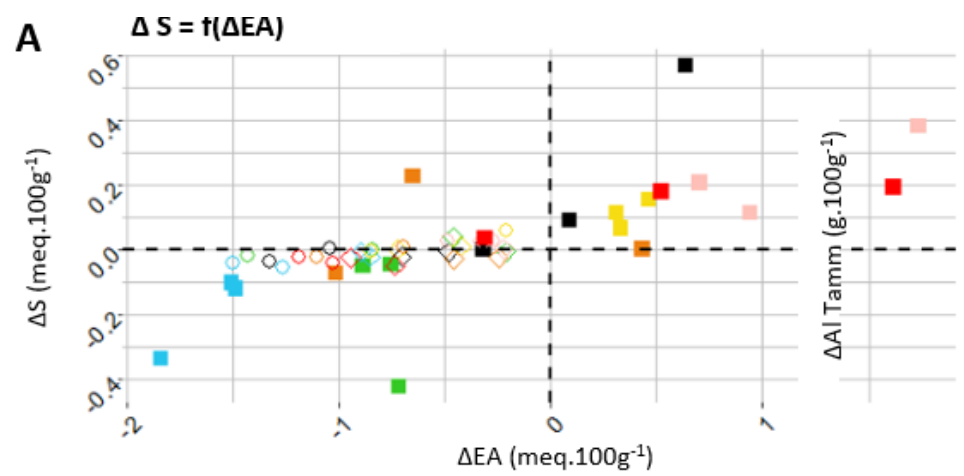

\section{B $\triangle$ Al Tamura $=f(\triangle C E C)$}

\section{C $\Delta \mathrm{CEC}=\mathrm{f}\left(\Delta \mathrm{pH} \mathrm{H}_{\mathrm{KCl}}\right)$}
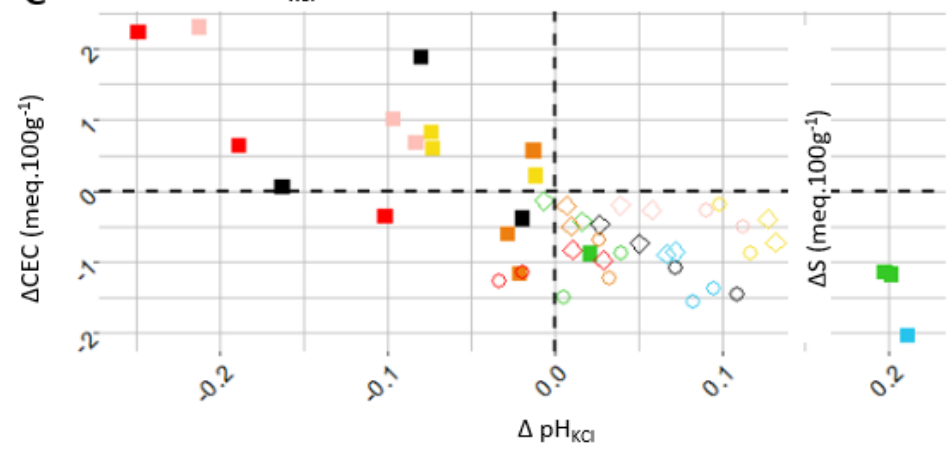

E $\quad \Delta C E C=f(\Delta C)$
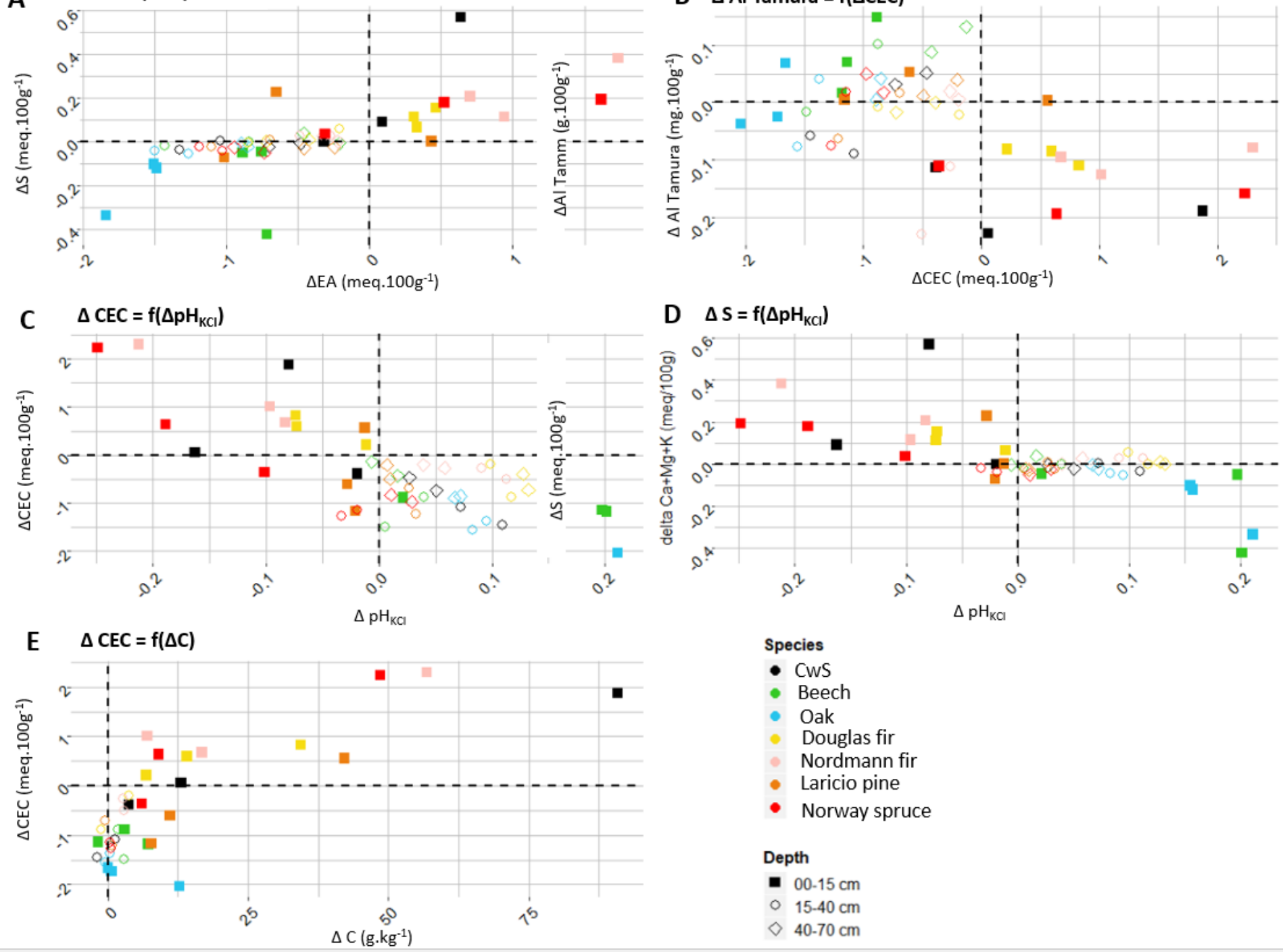

D $\Delta \mathrm{S}=\mathrm{f}\left(\Delta \mathrm{pH}_{\mathrm{KCl}}\right)$

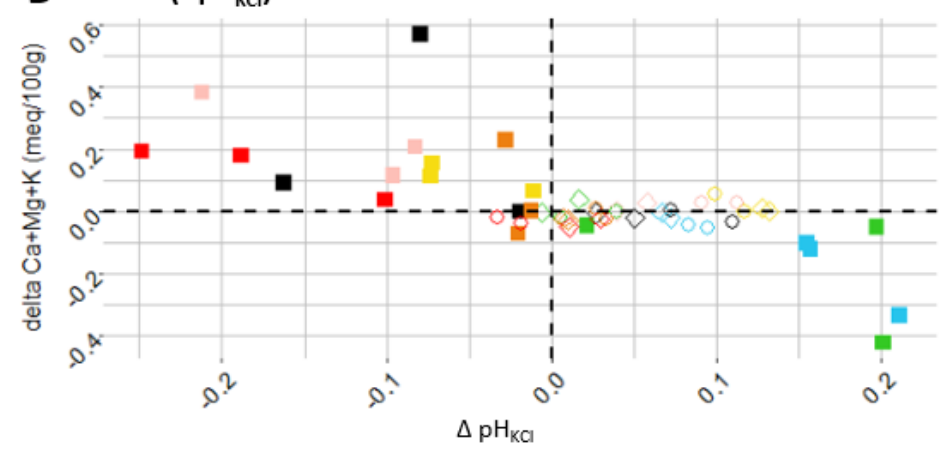

Species

- CwS

- Beech

- Oak

Douglas fir

Nordmann fir

- Laricio pine

- Norway spruce

Depth

- $00-15 \mathrm{~cm}$

- $15-40 \mathrm{~cm}$

$\diamond 40.70 \mathrm{~cm}$

\section{Figure 8}

Relationships between the variations, noted $\Delta$, (between 2001 and 2019) of different soil chemical properties for the different tree species and sampled soil layers. A : $\Delta S=f(\Delta E A), B: \Delta$ Al Tamura $=f(\Delta C E C)$, $C: \Delta C E C=f(\Delta p H K C l), D: \Delta S=f(\Delta p H K C l), E: \Delta C E C=f(\Delta C)$. 

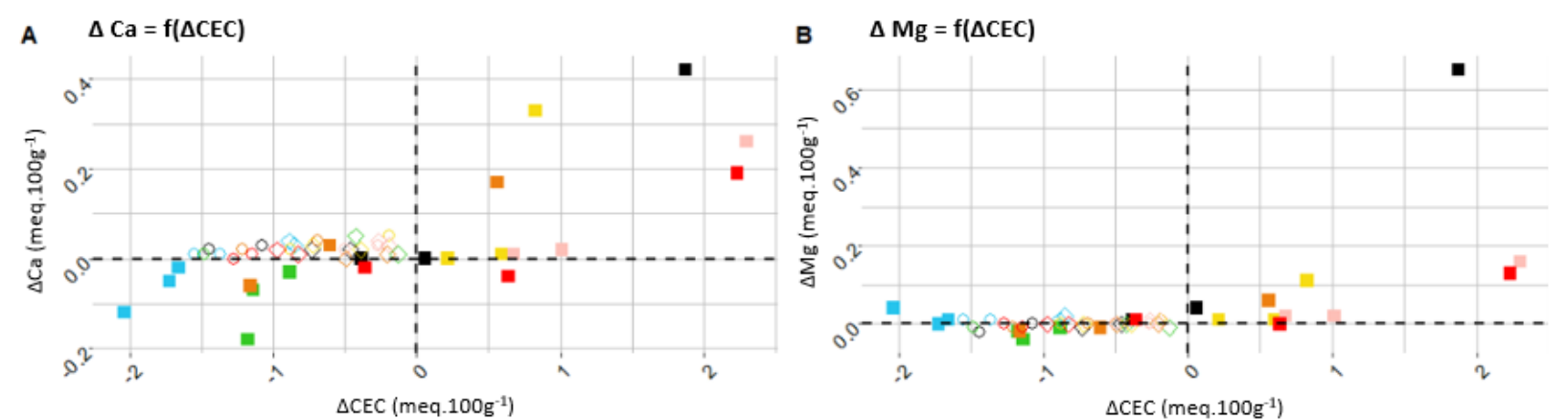

C $\Delta K=f(\Delta C E C)$

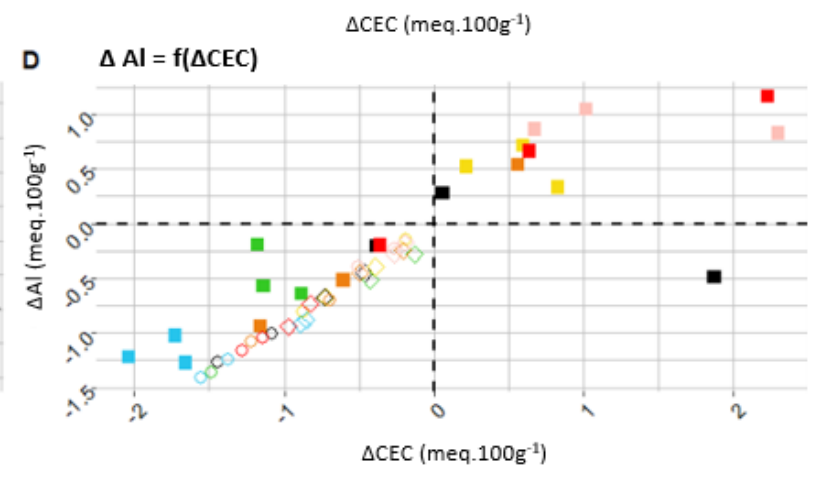

Species

- CWS

- Beech

- Oak

Douglas fir

- Nordmann fir

- Laricio pine

- Norway spruce

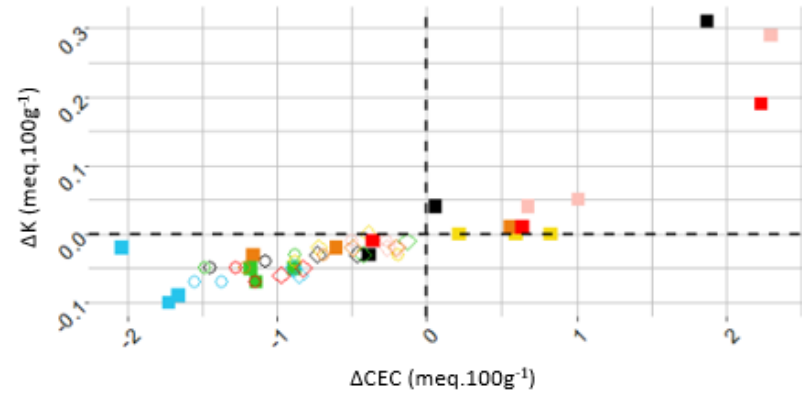

Depth

- $00-15 \mathrm{~cm}$

- $15-40 \mathrm{~cm}$

$\checkmark 40.70 \mathrm{~cm}$

Figure 9

Relationship between the variations of the CEC and exchangeable cations for the different tree species and sampled soil layers. $A: \Delta C a=f(\triangle C E C), B: \Delta M g=f(\Delta C E C), C: \Delta K=f(\triangle C E C), D: \Delta A l=f(\Delta C E C)$.

\section{Ca Organic Layer}

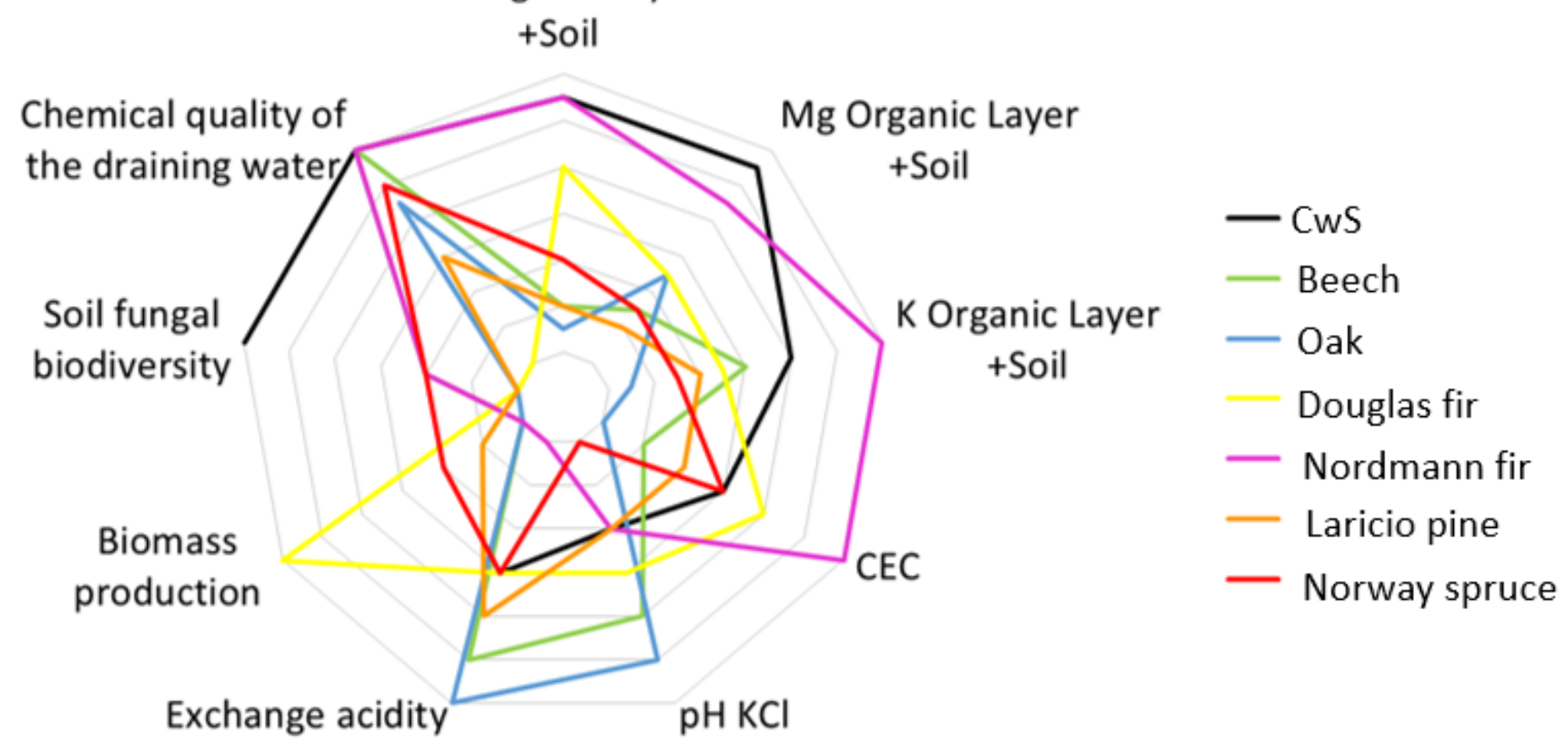

Figure 10 
Comparison of multiple criteria each assessing different functions of the ecosystem for the different tree species. Each criteria corresponds to a grade between 1 (center of the diagram) and 7 (outer ring) and corresponds to a relative classification of the seven tree species, 7 being the best grade.
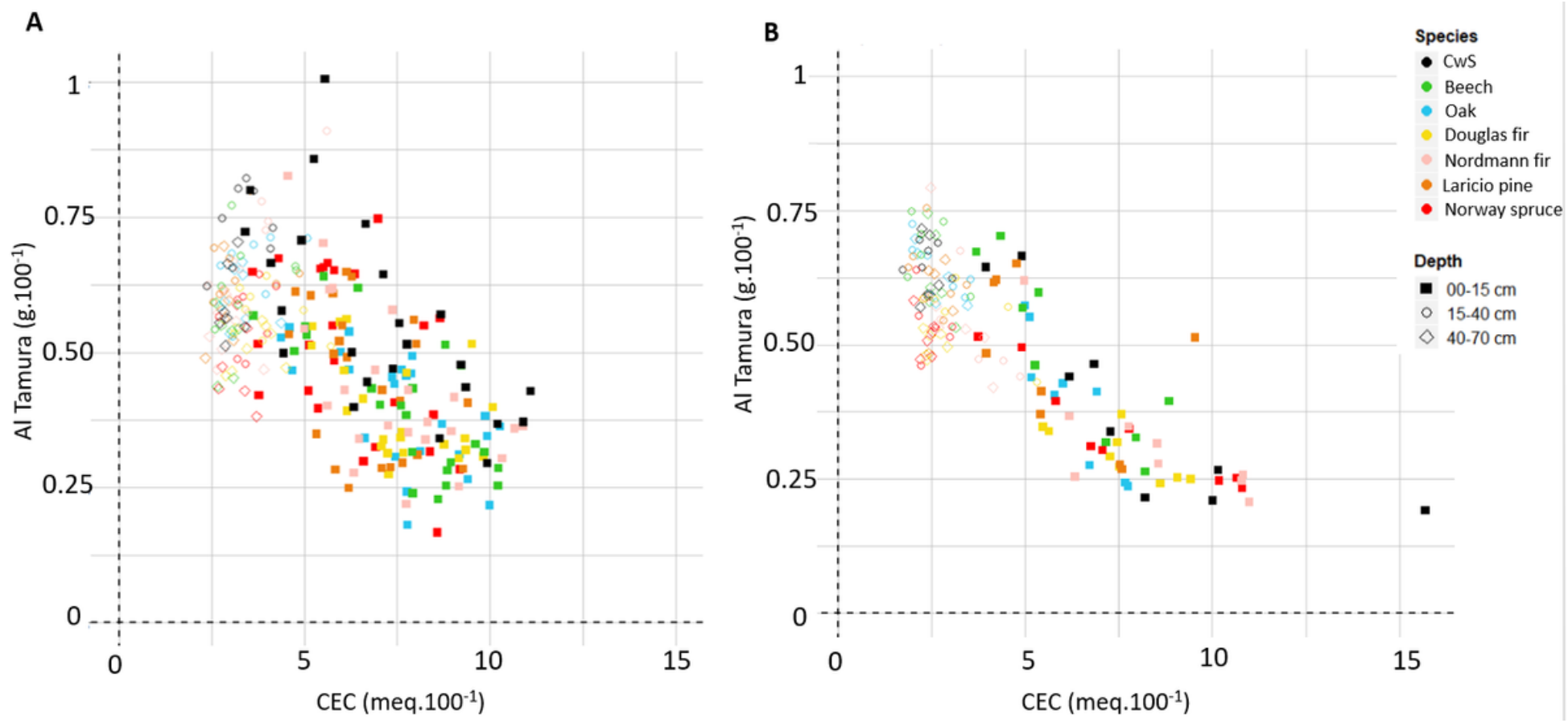

Figure 11

Relationship between CEC and Al Tamura in 2001 (A) and 2019 (B) for the different tree species and sampled soil layers. 


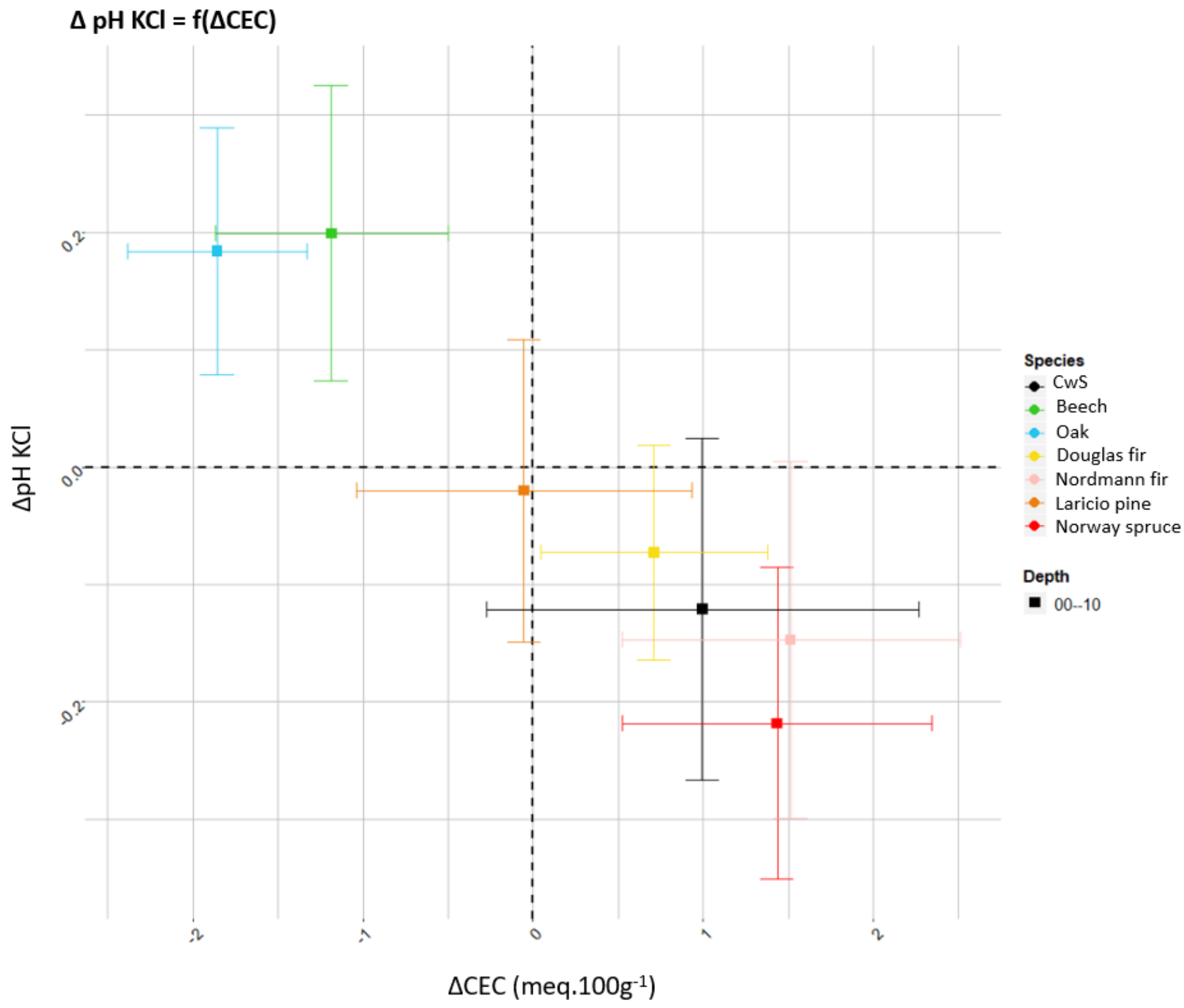

Figure 12

Relationship between the variations of the $\mathrm{CEC}$ and $\mathrm{pH} \mathrm{KCl}$, noted $\Delta$ (difference between the 2019 and 2001 values) in the 0-10 cm soil layer for the different tree species. The standard deviations were estimated with a Monte-Carlo simulation.

\section{Supplementary Files}

This is a list of supplementary files associated with this preprint. Click to download.

- Supplementarymaterial.docx 